\title{
Short Duration Alagebrium Chloride Therapy Prediabetes Does Not Inhibit Progression to Autoimmune Diabetes in an Experimental Model
}

\author{
Danielle J. Borg ${ }^{1,2}{ }^{\oplus}$, Pouya Faridi ${ }^{3} \mathbb{D}$, Kai Lin Giam ${ }^{3,+}$, Peta Reeves ${ }^{4,+}$, Amelia K. Fotheringham ${ }^{1} \mathbb{D}$, \\ Domenica A. McCarthy ${ }^{1}$, Sherman Leung ${ }^{1}$, Micheal S. Ward ${ }^{1}$, Brooke E. Harcourt ${ }^{5}$, Rochelle Ayala ${ }^{3}$, \\ Jean L. Scheijen ${ }^{6,7}$, David Briskey ${ }^{8} \mathbb{1}$, Nadine L. Dudek ${ }^{3}$, Casper G. Schalkwijk ${ }^{6,7}$, Raymond Steptoe ${ }^{4, \ddagger \text {, }}$ \\ Anthony W. Purcell ${ }^{3, \mp(1)}$ and Josephine M. Forbes $1,5,9, *$
}

Citation: Borg, D.J.; Faridi, P.; Giam, K.L.; Reeves, P.; Fotheringham, A.K.; McCarthy, D.A.; Leung, S.; Ward, M.S.; Harcourt, B.E.; Ayala, R.; et al. Short Duration Alagebrium Chloride Therapy Prediabetes Does Not Inhibi Progression to Autoimmune Diabetes in an Experimental Model. Metabolites 2021, 11, 426. https://doi.org/ $10.3390 /$ metabo11070426

Academic Editors: Melkam Kebede and Belinda Yau

Received: 24 May 2021

Accepted: 22 June 2021

Published: 28 June 2021

Publisher's Note: MDPI stays neutral with regard to jurisdictional claims in published maps and institutional affiliations.

Copyright: (c) 2021 by the authors. Licensee MDPI, Basel, Switzerland. This article is an open access article distributed under the terms and conditions of the Creative Commons Attribution (CC BY) license (https:// creativecommons.org/licenses/by/ $4.0 /)$.
1 Glycation and Diabetes Complications, Mater Research Institute, The University of Queensland, Translational Research Institute, Brisbane, QLD 4102, Australia; danielle.borg@mater.uq.edu.au (D.J.B.); amelia.fotheringham@mater.uq.edu.au (A.K.F.); domenica.mccarthy@mater.uq.edu.au (D.A.M.); sherman.leung@mater.uq.edu.au (S.L.); michael.ward5@msd.com (M.S.W.); brooke.harcourt@unimelb.edu.au (B.E.H.)

2 Pregnancy and Development, Mater Research Institute, The University of Queensland, South Brisbane, QLD 4101, Australia

3 Infection and Immunity Program, Department of Biochemistry and Molecular Biology, Biomedicine Discovery Institute, Monash University, Melbourne, VIC 3800, Australia; pouya.faridi@monash.edu (P.F.); kailin.giam@thermofisher.com (K.L.G.); rochelle.ayala.perez@monash.edu (R.A.); nadinedudekart@gmail.com (N.L.D.); anthony.purcell@monash.edu (A.W.P.)

4 Tolerance and Autoimmunity Group, The University of Queensland Diamantina Institute, Translational Research Institute, Brisbane, QLD 4102, Australia; peta.zorzetto@gmail.com (P.R.); r.steptoe@uq.edu.au (R.S.)

5 Murdoch Children's Research Institute, Royal Children's Hospital, Melbourne, VIC 3052, Australia

6 Laboratory for Metabolism and Vascular Medicine, Department of Internal Medicine, Maastricht University, 6211 Maastricht, The Netherlands; j.scheijen@maastrichtuniversity.nl (J.L.S.); c.schalkwijk@maastrichtuniversity.nl (C.G.S.)

7 Cardiovascular Research Institute Maastricht, 6211 Maastricht, The Netherlands

8 School of Human Movement and Nutrition Sciences, The University of Queensland, Brisbane, QLD 4067, Australia; d.briskey@uq.edu.au

9 Mater Clinical School, The University of Queensland, Brisbane, QLD 4101, Australia

* Correspondence: josephine.forbes@mater.uq.edu.au; Tel.: +61-7-3443-7642

$+\quad$ These authors contributed equally.

$\ddagger$ These senior authors contributed equally.

Abstract: Mechanisms by which advanced glycation end products (AGEs) contribute to type 1 diabetes (T1D) pathogenesis are poorly understood. Since life-long pharmacotherapy with alagebrium chloride (ALT) slows progression to experimental T1D, we hypothesized that acute ALT therapy delivered prediabetes, may be effective. However, in female, non-obese diabetic (NODShiLt) mice, ALT administered prediabetes (day 50-100) did not protect against experimental T1D. ALT did not decrease circulating AGEs or their precursors. Despite this, pancreatic $\beta$-cell function was improved, and insulitis and pancreatic CD $45.1^{+}$cell infiltration was reduced. Lymphoid tissues were unaffected. ALT pre-treatment, prior to transfer of primed GC98 CD8 ${ }^{+} \mathrm{T}$ cell receptor transgenic $\mathrm{T}$ cells, reduced blood glucose concentrations and delayed diabetes, suggesting islet effects rather than immune modulation by ALT. Indeed, ALT did not reduce interferon- $\gamma$ production by leukocytes from ovalbumin-pre-immunised NODShiLt mice and NODscid recipients given diabetogenic ALT treated NOD splenocytes were not protected against T1D. To elucidate $\beta$-cell effects, NOD-derived MIN6N8 $\beta$-cell major histocompatibility complex (MHC) Class Ia surface antigens were examined using immunopeptidomics. Overall, no major changes in the immunopeptidome were observed during the various treatments with all peptides exhibiting allele specific consensus binding motifs. As expected, longer MHC Class Ia peptides were captured bound to $\mathrm{H}-2 \mathrm{D}^{\mathrm{b}}$ than $\mathrm{H}-2 \mathrm{~K}^{\mathrm{b}}$ under all conditions. Moreover, more 10-12 mer peptides were isolated from $\mathrm{H}-2 \mathrm{D}^{\mathrm{b}}$ after AGE modified bovine serum 
albumin (AGE-BSA) treatment, compared with bovine serum albumin (BSA) or AGE-BSA+ALT treatment. Proteomics of MIN6N8 cells showed enrichment of processes associated with catabolism, the immune system, cell cycling and presynaptic endocytosis with AGE-BSA compared with BSA treatments. These data show that short-term ALT intervention, given prediabetes, does not arrest experimental T1D but transiently impacts $\beta$-cell function.

Keywords: advanced glycation end products; alagebrium chloride; cross-link breaker; immunopeptidome; MIN6N8 cell line; NOD mouse; autoimmune diabetes; type 1 diabetes

\section{Introduction}

Advanced glycation end products (AGEs) are formed by irreversible modifications of proteins or lipids with reducing sugars [1]. AGEs are synthesized endogenously in vivo and are ingested excessively in the western diet [2], although the availability of dietary AGEs and how they contribute to pathophysiological changes in the body remains to be fully understood [3]. AGEs are postulated to be regulated by multiple scavenger receptors expressed on a number of cell types, including the pattern recognition receptor for AGEs (RAGE), which can trigger events such as cellular adhesion and spreading [4,5], migration [6-8], and cytokine production [9] via nuclear factor kappa-light-chain-enhancer of activated B cells (NF-kB) activation [3].

Circulating AGEs are independent predictors of progression to type 1 diabetes (T1D) in islet cell autoantibody-positive children [10]. A smaller study in children and adolescents with pancreatic islet autoantibodies who were first-degree relatives of individuals with T1D, showed that progression to overt diabetes correlated with high circulating concentrations of AGEs [11]. In a population based nested case-control study, polymorphisms in the gene that encode for RAGE, advanced glycosylation end product-specific receptor (AGER), conferred increased T1D risk and reduced circulating soluble RAGE concentrations in young children with ketoacidosis carrying the HLA-DR3/DQ4 haplotype [12]. Additional studies have confirmed that in vitro excess AGE exposure results in pancreatic $\beta$-cell dysfunction reducing glucose stimulated insulin synthesis and secretion [11,13-15], increasing apoptosis [11,13], and mitochondrial abnormalities [11,16]. In vivo, acute AGE injections provided to healthy rodents [11,13], as well as chronic dietary AGE intake [17-19], each initiated $\beta$-cell dysfunction, resulting in insulin secretory deficiencies compared to control groups $[11,13,16-19]$. Temporal changes in circulating AGEs and RAGE expression are apparent pre-diabetes in the mouse model for T1D, non-obese diabetic (NOD) mice [20] when compared to non-diabetic NODscid mice [21].

Thus, it is not surprising that anti-AGE therapies, such as diets low in AGEs [18], or prophylactic injections of soluble RAGE, a decoy receptor for cellular RAGE, reverse insulin secretion defects, dampen pancreatic islet immune cell infiltration and delay experimental autoimmune diabetes in NOD mice [22]. We have previously demonstrated that continuous, life-long administration of the therapeutic agent alagebrium (4,5-dimethyl3-(2-oxo2-phenylethyl)-thiazolium chloride (ALT)), thought to cleave the intermediate $\alpha$-dicarbonyls compounds which form AGEs [23,24], reduced diabetes progression in the NODShiLt mouse and protected $\beta$-cell function [11].

What is currently unknown is whether effects seen with AGE-lowering strategies, such as ALT on pancreatic $\beta$-cell function, are independent of improvements in the immune system in autoimmune diabetes. Secondly, it is unclear if a shorter duration of therapy prediabetes could delay autoimmune diabetes onset. To address this, we used the NOD mouse-derived $\beta$-cell MIN6N8 cell line and NOD strains with varying susceptibility to autoimmune diabetes and examined the efficacy of short-term ALT administration prior to diabetes onset, from day 50-100 of life on diabetes development. 


\section{Results}

2.1. Short-Term AGE Lowering Therapy with ALT Prediabetes Does Not Impact Experimental Autoimmune Diabetes Development in NODShiLt Mice

Previous studies have shown benefits of AGE-lowering therapies in arresting autoimmune diabetes development in NODShiLt mice [11]. Fifty days of daily ALT therapy from 50 to 100 days of life modestly delayed the age of diabetes onset (control $141 \pm 32$ days vs. ALT $171 \pm 38$ days, $p=0.05$; Figure 1A), but there were no differences in disease incidence when compared to control mice by the study end (control: 11/18; alagebrium: 15/20 mice, $p=0.5$; Figure $1 \mathrm{~A})$.

A
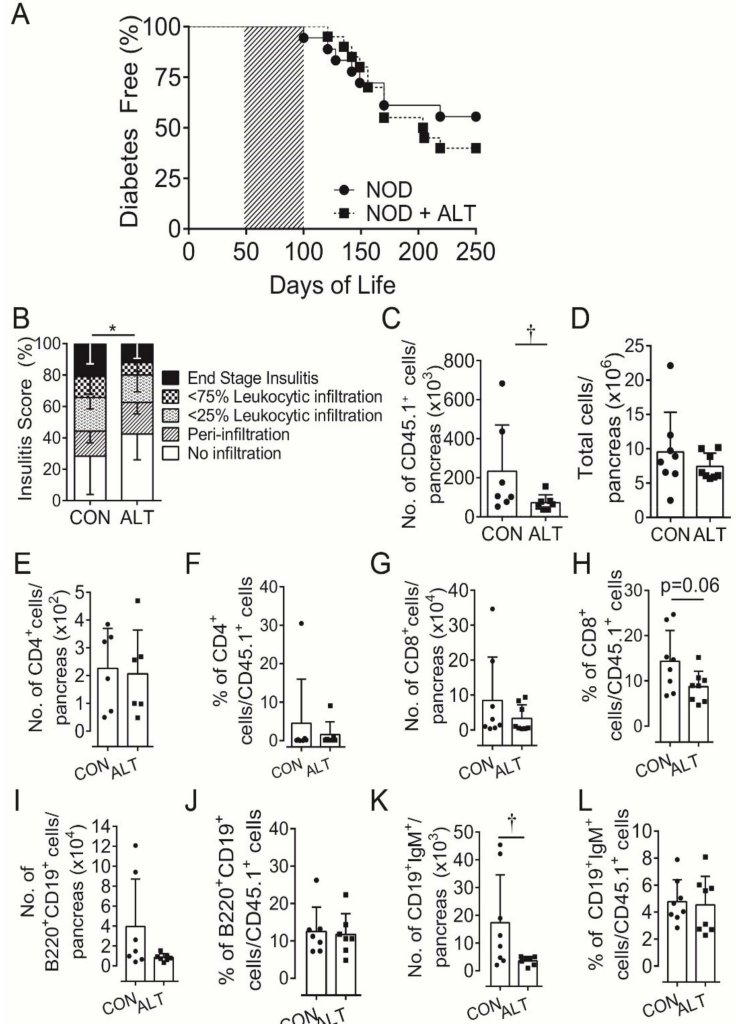

$\mathrm{F}$

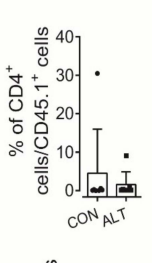

G
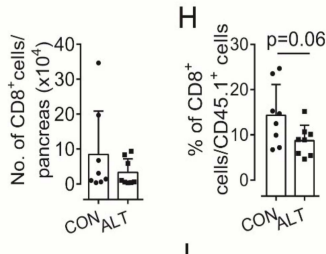

$\mathrm{K}$
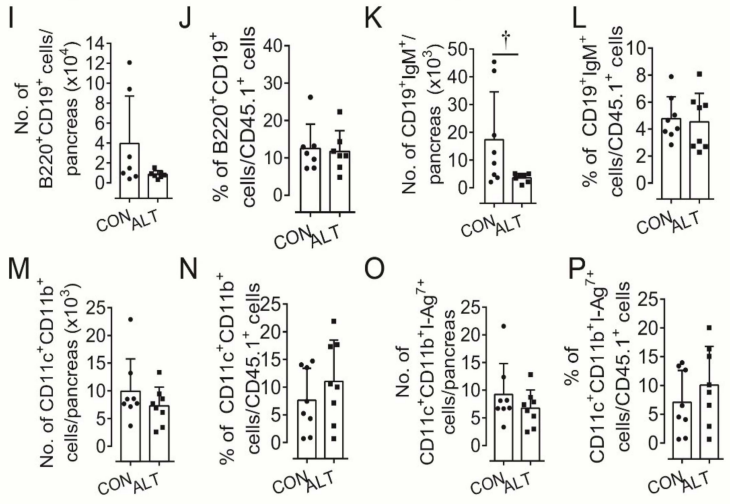

$\mathrm{O}$

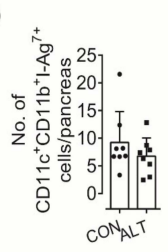

$P_{+}$
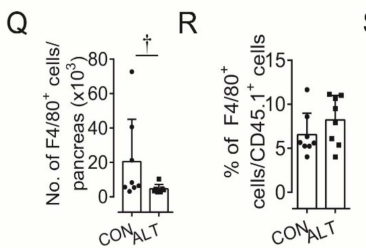

$S$
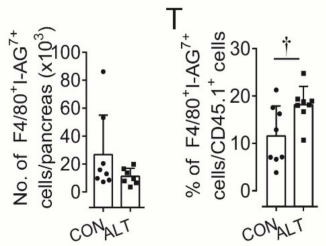

Figure 1. Short term AGE lowering therapy pre-diabetes in NOD mice does not protect against diabetes development despite attenuating $\beta$-cell infiltration. (A) Diabetes incidence of female NODShiLt (NOD) mice ( $n=18-20$ /group) from day 50 to 100 of life (shaded grey) were untreated (NOD, $\bullet$ ) or treated with the AGE lowering therapy alagebrium chloride (ALT, $1 \mathrm{mg} / \mathrm{kg} /$ day, s.c; $\mathbf{\square}$ ). Mice were monitored daily, blood glucose tested weekly for diabetes incidence and mice were euthanised when either blood glucose concentrations exceeded $15 \mathrm{mmol} / \mathrm{L}$ for two consecutive days, day 250 of life was reached without diabetes diagnosis. (B) Islet immune cell infiltration at day 90 of life shown as 
mean percentage of islets with no infiltrate (white), perivascular/periductal infiltrate (striped), $<25 \%$ infiltrate (arrowhead), $<75 \%$ infiltrate (checkerboard) or end stage insulitis (black) after no therapy (CON) or 40 days alagebrium chloride (ALT) treatment ( $n=4$ mice/group, $5 \mu \mathrm{m}$ sections). After 30 days of ALT therapy, pancreata were digested and infiltrating immune cells quantified via surface staining for $(C)$ total number of leukocyte common antigen positive $\left(C D 45.1^{+}\right)$immune cells, (D) total number and proportions of $(\mathbf{E}, \mathbf{F}) \mathrm{CD}^{+} \mathrm{T}$ cells, $(\mathbf{G}, \mathbf{H}) \mathrm{CD} 8^{+} \mathrm{T}$ cells, $(\mathbf{I}, \mathbf{J}) \mathrm{CD} 19^{+} \mathrm{B}^{2} 20^{+}$,

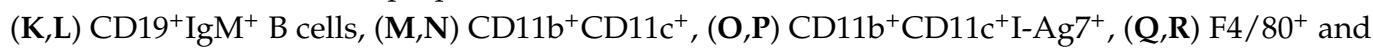
$(\mathbf{S}, \mathbf{T}) \mathrm{F} 4 / 80^{+} \mathrm{I}-\mathrm{Ag} 7^{+}$immune cells $(n=7-8 \mathrm{mice} /$ group; $n=2$ experiments). Data represented as mean \pm SD. For analysis in $(\mathbf{C}, \mathbf{D})$ data was log transformed. ${ }^{*} p=0.0005$ vs. NOD (Chi-square); $+p<0.05$ vs. NOD (Student's T Test).

\subsection{Short-Term Therapy with ALT Increases Insulin Secretion Pre-Diabetes}

Beta cell function was examined in mice during and directly after ALT therapy. At approximately day 75 of life (after $\sim 25$ days of ALT therapy), intraperitoneal (IPGTT; Table 1; Figure S1A,B) and oral (OGTT; Table 1; Figure S1C,D) glucose tolerance tests were performed in two separate cohorts of mice. In both tests, insulin secretion across the test duration $\left(\mathrm{AUC}_{\text {INSULIN }}\right)$ was significantly greater in mice given ALT therapy (Table 1 ; Figure S1A-D). In addition, the first phase insulin response and action during the first 15 min of the IPGTT was higher in ALT treated mice (Table 1, AUC INSULIN $_{\text {:AUC }}$ GLUCOSE; Figure S1B). By day 107 of life, just after the completion of the ALT treatment period, circulating non-fasted insulin concentrations appeared higher in ALT treated mice when compared to controls but did not reach significance ( $p=0.06$; Table 2). During OGTT

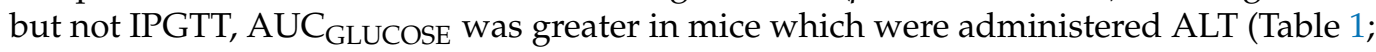
Figure S1C).

Despite the slight elevation in circulating insulin concentrations over the course of ALT therapy (Table 2), blood glucose concentrations, body weight and glycated haemoglobin remained unchanged over the course of treatment (Table 2). When examined towards the end of the ALT treatment period ( $\sim 40$ days), pancreatic islets were a similar size to those seen in control mice (Figure S1E) and did not differ in insulin (Figure S1F,G) or proinsulin (Figure S3H,I) staining as compared to controls. Overall, these data imply that ALT may have a temporal effect on pancreatic islet function early in diabetes progression.

\subsection{AGEs and Precursor Molecules Were Unaffected by Short Term ALT Therapy}

AGE precursor molecules, the dicarbonyls methylglyoxal (MGO), glyoxal (GO), and 3-deoxyglucosone (3-DG) remained unchanged across the treatment period in NODShiLt mice receiving ALT therapy (Figure S2A-C). Although these dicarbonyls did not associate with changes in circulating insulin (data not shown), GO and 3-DG associated positively with glycated haemoglobin after 30 days of therapy (Figure S2D,E). Collectively, this data suggests that short-term, intensive alagebrium therapy does not reduce reactive dicarbonyl compounds or stop diabetes progression. There was a trend towards the AGE carboxyethyl-lysine (CEL) being reduced after ALT therapy, which was not observed with other AGE modifications such as carboxylmethyl-lysine (CML) and methylglyoxal-derived hydroimiadazolone (MG-H1) (Figure S2F). 


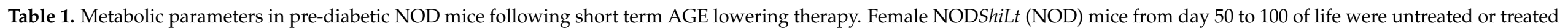

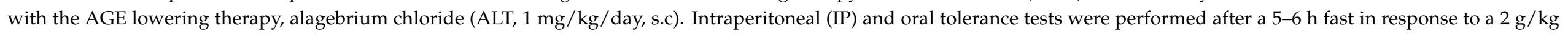

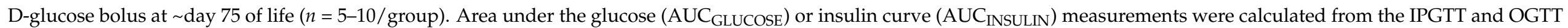

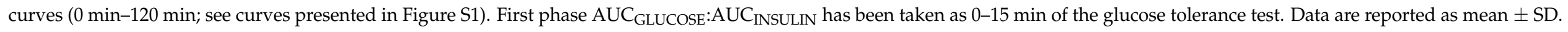
$\dagger p=0.002$ vs. NOD (Unpaired Student's $t$-test); $\ddagger p<0.0001$ vs. NOD (Mann-U Whitney); $p=0.02$ vs. NOD (Unpaired Student's $t$-test).

\begin{tabular}{|c|c|c|c|c|c|c|c|c|}
\hline & \multicolumn{3}{|c|}{ IP Glucose Tolerance Test } & \multicolumn{3}{|c|}{ Oral Glucose Tolerance Test } & \multirow{2}{*}{$\begin{array}{l}\text { Fasting Insulin } \\
\quad(\mathrm{p} \cdot \mathrm{mol} / \mathrm{L})\end{array}$} & \multirow{2}{*}{$\begin{array}{c}\text { Fasting } \\
\text { Proinsulin } \\
\text { (p.mol/L) }\end{array}$} \\
\hline & $\begin{array}{c}\text { AUC }_{\text {GLUCOSE }} \\
(\mathrm{m} \cdot \mathrm{mol} / \mathrm{L} / \mathrm{min})\end{array}$ & $\begin{array}{c}\text { AUC } \\
(\mathrm{n} \cdot \mathrm{mol} / \mathrm{L} / \mathrm{min})\end{array}$ & $\begin{array}{l}\text { AUC }_{\text {INSULIN }} \\
\text { AUC }_{\text {GLUCOSE }}\end{array}$ & $\begin{array}{c}\mathrm{AUC}_{\mathrm{GLUCOSE}} \\
(\mathrm{m} \cdot \mathrm{mol} / \mathrm{L} / \mathrm{min})\end{array}$ & $\begin{array}{c}\text { AUC }_{\text {INSULIN }} \\
(\mathrm{n} \cdot \mathrm{mol} / \mathrm{L} / \mathrm{min})\end{array}$ & $\begin{array}{l}\text { AUC }_{\text {INSULIN }} \\
\text { AUC }_{\text {GLUCOSE }}\end{array}$ & & \\
\hline NOD & $923.9 \pm 81.4$ & $37.3 \pm 18.0$ & $0.02 \pm 0.008$ & $903.5 \pm 58.5$ & $10.2 \pm 0.6$ & $0.03 \pm 0.008$ & $411.9 \pm 391.3$ & $14.0 \pm 10.0$ \\
\hline $\mathrm{NOD}+\mathrm{ALT}$ & $868.5 \pm 45.5$ & $75.8 \pm 28.7+$ & $0.12 \pm 0.04 \ddagger$ & $1036.0 \pm 78.9 *$ & $11.8 \pm 1.2 *$ & $0.03 \pm 0.004$ & $398.4 \pm 240.8$ & $16.2 \pm 7.6$ \\
\hline
\end{tabular}

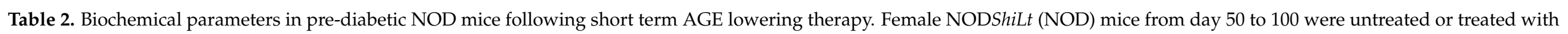

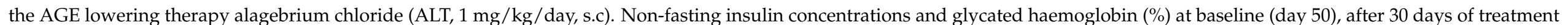

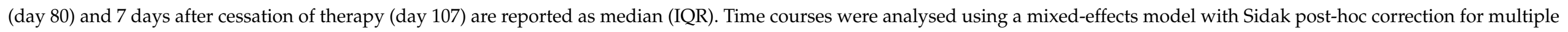

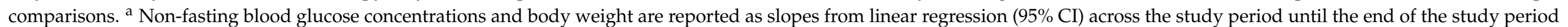
(day 250 of life).

\begin{tabular}{|c|c|c|c|c|c|c|c|c|}
\hline & \multicolumn{3}{|c|}{ Non-Fasting Insulin (ng/mL) } & \multicolumn{3}{|c|}{ Glycated Haemoglobin (\%) } & \multirow{2}{*}{$\begin{array}{l}\text { Non-Fasting } \\
\text { Blood Glucose }\end{array}$} & \multirow{2}{*}{ Body Weight } \\
\hline & Day 50 & 80 & 107 & Day 50 & 80 & 107 & & \\
\hline NOD & $0.34(0.24-0.51)$ & $0.31(0.26-0.45)$ & $0.30(0.25-0.47)$ & $3.12(2.5-3.7)$ & $4.4(2.7-5.2)$ & $3.8(2.9-5.2)$ & $\begin{array}{c}0.0059 \\
(0.002-0.010)\end{array}$ & $\begin{array}{c}0.0429 \\
(0.040-0.048)\end{array}$ \\
\hline $\mathrm{NOD}+\mathrm{ALT}$ & $0.37(0.27-0.57)$ & $0.32(0.26-0.74)$ & $0.44(0.25-1.3)$ & $2.9(2.5-3.6)$ & $3.4(2.5-4.1)$ & $3.2(3.0-4.0)$ & $\begin{array}{c}0.0101 \\
(0.005-0.016)\end{array}$ & $\begin{array}{c}0.0393 \\
(0.036-0.042)\end{array}$ \\
\hline
\end{tabular}




\subsection{Localised Pancreatic but Not Lymph Node or Splenic Immune Cells Are Modulated by Short-Term ALT Therapy}

Based on the temporal effects on insulin secretion in the present study and our previous finding that long-term ALT administration reduced diabetes incidence in NOD mice [11], we hypothesized that local immunopathology within the pancreas may be altered. Semi-quantitative insulitis scoring of immune cell infiltrate after 40 days of ALT therapy confirmed reduced islet infiltration compared with control mice (Figure 1B). Whole pancreatic digests after 30 days of therapy showed a consistently lower number of CD45.1 ${ }^{+}$ leukocytes per pancreas in ALT-treated mice as compared with untreated mice (Figure 1C). Total pancreatic cell numbers (Figure 1D) [25], did not differ between groups.

Within CD45.1 $1^{+}$cell populations in the pancreas (Figure S3A; gating strategy) the number and proportions of $\mathrm{CD}^{+} \mathrm{T}$ cells (Figure $\left.1 \mathrm{E}, \mathrm{F}\right), \mathrm{B} 220^{+} \mathrm{CD} 19^{+} \mathrm{B}$ cells (Figure $1 \mathrm{I}, \mathrm{J}$ ),

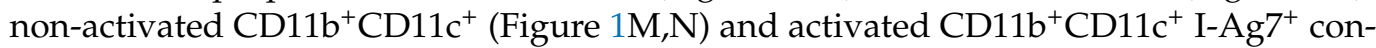
ventional dendritic cells (cDC; Figure 1O,P) were similar between groups. However, the pancreatic $\mathrm{CD} 45.1^{+}$cell populations tended to contain a lower percentage of $\mathrm{CD} 8^{+} \mathrm{T}$ cells although numbers remained unchanged (Figure $1 \mathrm{G}, \mathrm{H}$ ) with ALT. There were fewer mature $\mathrm{CD} 9^{+} \mathrm{IgM}^{+} \mathrm{B}$ cells and $\mathrm{F} 4 / 80^{+}$macrophages numbers (Figure $1 \mathrm{~K}, \mathrm{Q}$ ) but not proportions and (Figure $1 \mathrm{~L}, \mathrm{R}$ ), and higher proportions but not numbers of activated $\mathrm{F} 4 / 80^{+} \mathrm{I}-\mathrm{Ag} 7^{+}$ macrophages (Figure 1S,T) after ALT treatment compared to control.

Since islet antigen-specific $\mathrm{T}$ cells are commonly primed in the pancreatic lymph nodes by antigen-presenting cells [26,27], we next set out to verify whether the decreases in infiltrating pancreatic leukocytes with ALT were due to modulation of the local lymph node milieu. Flow cytometry analysis (Figure S3B; gating strategy), of pancreatic lymph node ( $\mathrm{pLN}$ ) cell suspensions isolated after 30-40 days of ALT therapy showed no change in the absolute numbers and proportions of $\mathrm{CD}^{+}$(Figure S4A,B) and CD8 ${ }^{+} \mathrm{T}$ cells (Figure S4I,J). The number and proportions of naïve $\left(\mathrm{CD}^{+} 2^{+} \mathrm{CD} 44^{-}\right)$, effector/effector memory $\left(\mathrm{CD} 62^{-} \mathrm{CD}_{4} 4^{+}\right.$) or central memory $\left(\mathrm{CD} 62^{+} \mathrm{CD} 44^{+}\right) \mathrm{CD}^{+}$(Figure $\left.\mathrm{S} 4 \mathrm{C}-\mathrm{H}\right)$ or $\mathrm{CD} 8^{+}$ (Supplementary Figure S4K-P) T cell subsets remained unchanged. Similarly, regulatory T cells (Treg; CD4 ${ }^{+} \mathrm{CD} 25^{+} \mathrm{Foxp}^{+}$), thought to play a key role in autoimmune diabetes in NOD mice [28] and T1D in humans [29], were not different between groups (Figure S4Q-R). Similar to the pancreas, CD11b ${ }^{+}$CD11 $c^{+}$cDC (Figure S5A,B), and CD11b ${ }^{-}$CD $11 c^{+}$plasmacytoid dendritic cells (Figure S5C,D) remained unchanged between groups. Unlike the pancreas, $\mathrm{CD}_{19}{ }^{+} \mathrm{B} 220^{+} \mathrm{B}$ cells (Figure S4S,T) remained unchanged.

Flow cytometry analysis (Figure S3C; gating strategy) of cell suspensions prepared from spleens showed no change in numbers and proportions of dendritic cells (Figure S5E-H), CD4 ${ }^{+}$ (Figure S6A-G), CD8 ${ }^{+}$(Figure S6I-P) T cells, Tregs (Figure S6Q,R) or B cells (Figure S6S,T) after ALT therapy, with the exception of a reduced proportion of central memory $\mathrm{CD}^{+} \mathrm{T}$ cells (Figure $\mathrm{S} 6 \mathrm{H}$ ). Collectively, these results suggest that mice exposed to short-term ALT therapy have reduced proportions of pancreatic $\mathrm{CD}^{+}$and splenic central memory $\mathrm{CD} 4^{+} \mathrm{T}$ cells that could be subsequent to changes in pancreatic antigen presenting cell proportions.

\subsection{Pre-Treatment with ALT Delays Diabetes Development Following Adoptive Transfer of G9C8 CD8 T Cell Receptor (TCR) Transgenic Cytotoxic Lymphocytes}

To further explore the effects of ALT on $\beta$-cells during diabetes development, we adoptively transferred activated, diabetogenic NOD G9C8 CD8 TCR transgenic cytotoxic T lymphocytes, that recognize aa15-23 of the insulin B chain [30], into non-diabetic NODShiLt recipient mice that were pre-treated for 30-days with or without ALT. ALT delayed diabetes onset by an average of 18 days compared to controls and halved the number of mice which developed diabetes (20\% incidence with ALT pre-treatment and $40 \%$ incidence in untreated mice; Figure 2A). ALT pre-treatment decreased non-fasting blood glucose concentrations across the study duration ( $p=0.02$, Figure $2 \mathrm{~B}$ ). However, ALT pre-treatment exacerbated insulitis (Figure 2C), although this did not overtly reduce $\beta$-cell area (Figure 2D). Pancreatic expression of insulin (Figure 2E,F) remained unchanged. 
A

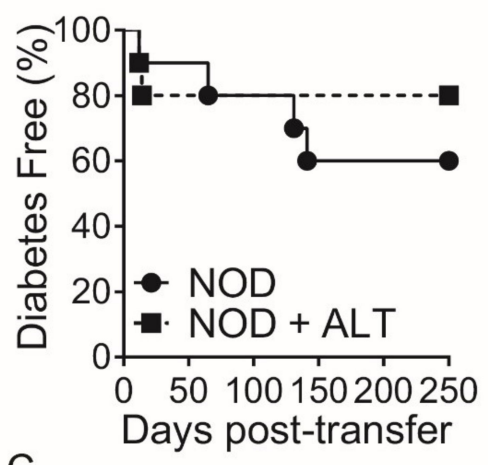

C

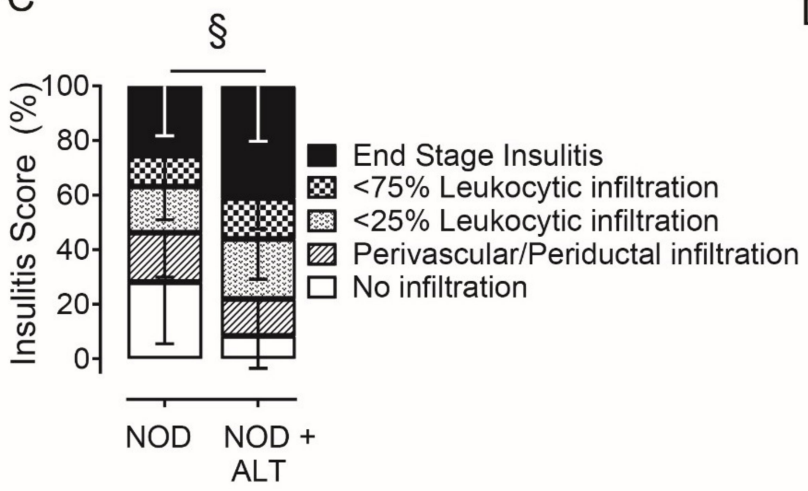

E

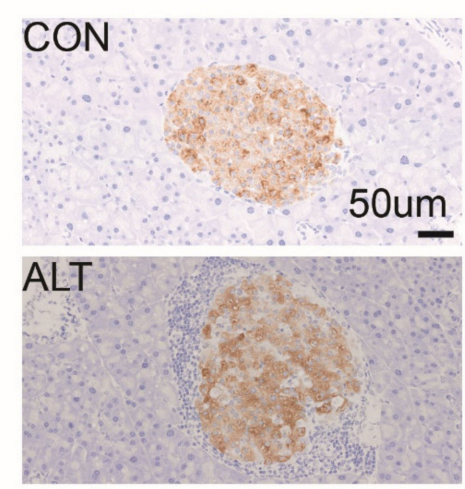

B

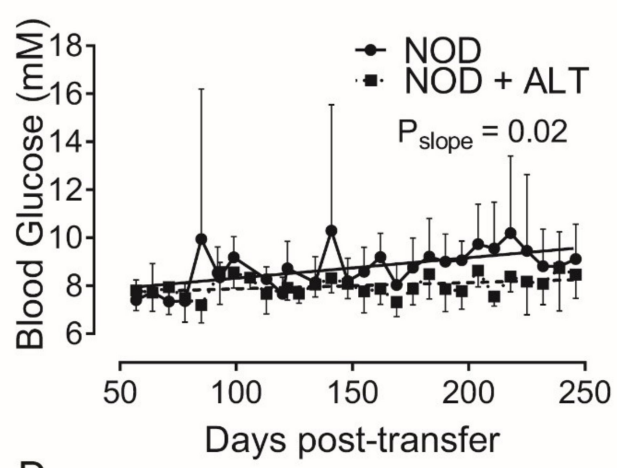

D

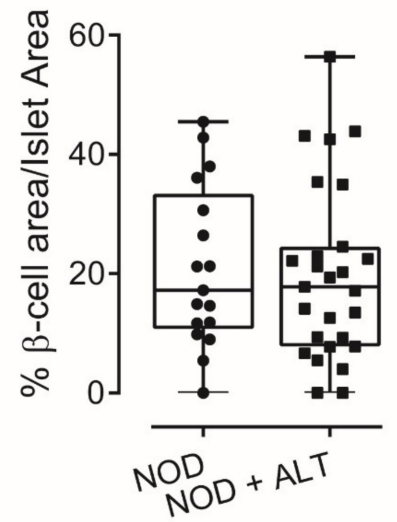

$\mathrm{F}$

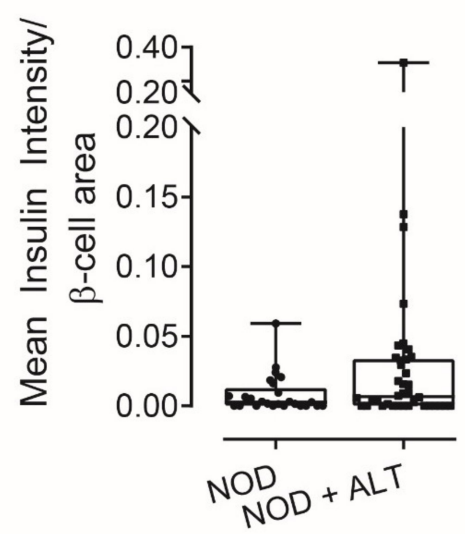

Figure 2. Alagebrium chloride delays diabetes development following adoptive transfer of G9C8 CD8 TCR transgenic cytotoxic lymphocytes. Diabetogenic splenocytes from NOD G9C8 CD8 TCR transgenic donors pre-primed with the aa15-23 of the insulin B chain $\left(1 \times 10^{7}\right.$ cells), were transferred into non-diabetic NODShiLt recipients $(n=10 /$ group; day 80 of life). NODShiLt recipients were pre-treated for 30 days with (NOD + ALT, $1 \mathrm{mg} / \mathrm{kg} /$ day, s.c; $\mathbf{\square}$, dashed line) or without alagebrium chloride (NOD, $\bullet$, solid line). The recipient mice were monitored daily, tested for blood glucose and diabetes diagnosed by two consecutive blood glucose measurements $>15 \mathrm{~m} \cdot \mathrm{mol} / \mathrm{L}$ and followed until diabetes diagnosis or until study end (day 250). (A) Diabetes incidence in NODShiLt recipients post-transfer of G9C8 cells. (B) Linear regression of non-fasting blood glucose concentrations over time, difference of slopes $p=0.02$. (C) Pancreatic immune cell infiltration at day 250 ( $n=6-8$ mice/group), shown as mean percentage of islets with no infiltrate (white), perivascular/periductal infiltrate (striped), $<25 \%$ infiltrate (arrowhead), $<75 \%$ infiltrate (checkerboard) or end stage insulitis (black) of untreated splenocytes (CON; circles) or Alagebrium-treated splenocytes (ALT; squares) $\S p<0.0001$, chi-square test. (D) $\beta$-cell area, determined from insulin IHC staining in (E) Representative images of islets detected with anti-insulin antibody in pancreatic sections taken from untreated $(\mathrm{CON})$ or treated mice $(\mathrm{ALT})$, scale bar $=50 \mu \mathrm{m}$. (F) Pancreatic expression of insulin ( $n=26-40$ sections/group, $n=2-39$ islets/section, $n=6-8$ mice/group, $5 \mu \mathrm{m}$ sections, $96 \mu \mathrm{m}$ apart. Data reported as either mean $\pm \mathrm{SD}$ or box and whisker plots reporting median, interquartile ranges and min and max values. 


\subsection{ALT Maintains Systemic Immune Function in the NODShiLt Mouse}

We next examined if ALT affected systemic cellular immune responses. After 28-32 days of ALT therapy, we determined the cytokine-response following an ovalbumin (OVA) challenge in splenocytes from pre-immunised NODShiLt mice one week after an ovalbumin immunisation (given at day 21-25 of treatment). Quantification of interferon- $\gamma$ (IFN- $\gamma$ ) producing splenocytes by ELISpot revealed no differences between untreated mice and ALT-treated mice (Figure 3A). Consistent with this, the ability to adoptively transfer diabetes to NODscid recipients by splenocytes from 28-32-day ALT-treated NODShiLt donors (9/13 diabetic; Figure 3B) was similar to that of control splenocytes (10/14 diabetic). The age at transfer and slight variances in cell number did not associate with diabetes transfer ( $p=0.06$ and $p=1.0$, respectively; cox regression). This suggests short-term ALT therapy does not compromise systemic leukocyte function.

A

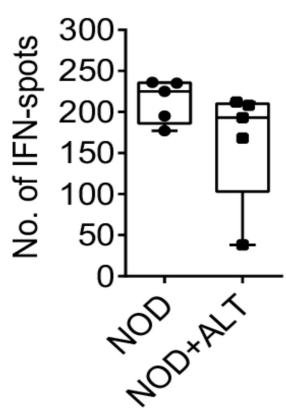

$\mathrm{B}$

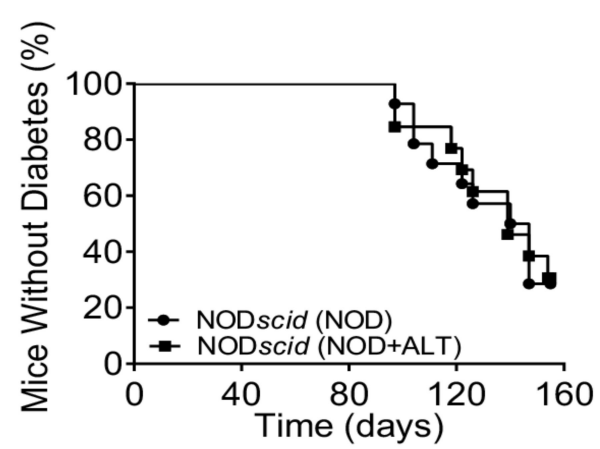

Figure 3. Systemic immune cells retain their function following short-term AGE lowering therapy with alagebrium chloride (ALT). (A) NODShiLt control mice (NOD, $\bullet$ ) and NODShiLt treated with alagebrium (NOD + ALT, $1 \mathrm{mg} / \mathrm{kg} /$ day, s.c; ) were immunised with OVA/QuilA and 1 week later spleens harvested and the number of cells producing IFN- $\gamma$ in responses to OVA restimulation enumerated with ELISpot. ( $n=3$ replicates from $n=5$ mice/group, $n=2$ independent experiments). (B) Diabetes incidence after adoptive transfer of control or ALT treated (for $\sim 30$ days) diabetogenic NODShiLt splenocytes into NODscid recipients aged 6-7 weeks old. $\mathrm{N}=13-14$ /recipient group $\left(1 \times 10^{6}-2 \times 10^{7}\right.$ cells/mouse). $\mathbf{N O D}+$ ALT into NODscid recipients; $\bullet$ NOD into NODscid recipients.

\subsection{Immunopeptidomics and Proteomics of Pancreatic Beta Cells Following ALT Therapy}

We have previously demonstrated in vitro that advanced glycation end product modified BSA (AGE-BSA) impairs insulin secretion and adenosine triphosphate (ATP) production in MIN6N8 cells, which was reversed by ALT treatment [11]. To examine whether chronic exposure to a high AGE environment and ALT treatment resulted in changes in the peptide repertoire presented by MHC class Ia (immunopeptidome), bound peptides (pMHC-I; H-2 $\mathrm{D}^{\mathrm{b}}$ and $\mathrm{H}-2 \mathrm{~K}^{\mathrm{b}}$ ) were immunoaffinity captured from treated MIN6N8 and sequenced via LC-MS/MS (Figure $4 \mathrm{~A}$ ). The complete dataset for both $\mathrm{D}^{\mathrm{b}}$ and $\mathrm{K}^{\mathrm{b}}$ are shown for untreated and treated MIN6N8 cells in Tables S1 and S2, respectively, and are accessible via the PRIDE data repository (see Data Availability Statement). Overall, no major changes in the immunopeptidome were observed during the various treatments with all peptides exhibiting allele specific consensus binding motifs. As expected, longer peptides were captured bound to $\mathrm{H}-2 \mathrm{D}^{\mathrm{b}}$ than $\mathrm{H}-2 \mathrm{~K}^{\mathrm{b}}$, with the $\mathrm{H}-2 \mathrm{D}^{\mathrm{b}}$ peptides tending to be of longer chain length with AGE-BSA treatment (Figure 4C), when compared with either unmodified BSA (control) or AGE-BSA+ALT. H-2 $\mathrm{K}^{\mathrm{b}}$ peptides were more abundant but did not appear to differ among groups. $\mathrm{H}-2 \mathrm{D}^{\mathrm{b}}$ and $\mathrm{H}-2 \mathrm{~K}^{\mathrm{b}}$ captured peptides were predominantly of 8-12 amino acids in length (Figure 4C) with similar bound motifs (Figure 4D), regardless of treatment (Figure S7A,B). Irrespective of the MHC-I class, the majority of H-2D ${ }^{b}$ and $\mathrm{H}-2 \mathrm{~K}^{\mathrm{b}}$ peptides that presented in each treatment, were found in at least one other condition (Figure 4E; Figure S7C), with differences likely reflecting subtle variation between experiments rather than significant changes to the bound peptide repertoire. The 8-mer 
YQLENYCN peptide (InsA $\mathrm{A}_{14-21}$ ) where cysteine is modified by a glutathione disulfide, was elevated during AGE-BSA treatment compared to BSA control (Figure 4F). After the addition of ALT therapy, YQLENYC(glutathione disulfide)N decreased to a level similar to that of the BSA control (Figure $4 \mathrm{~F}$ ).

A

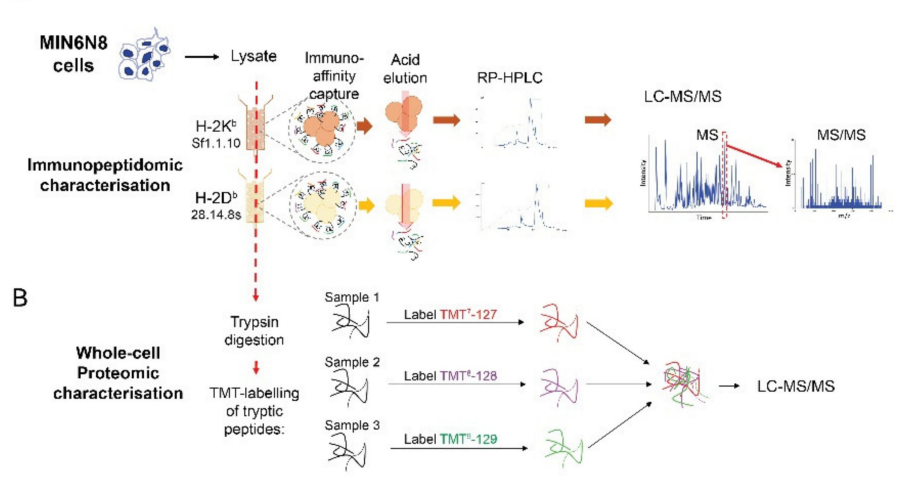

$E$

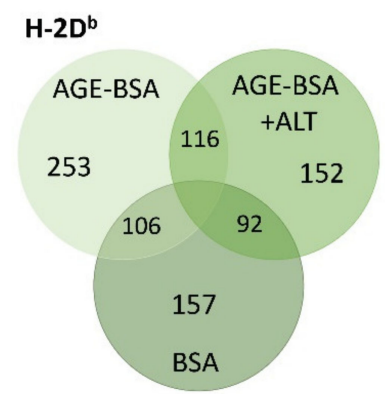

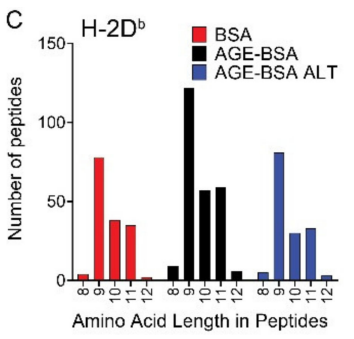
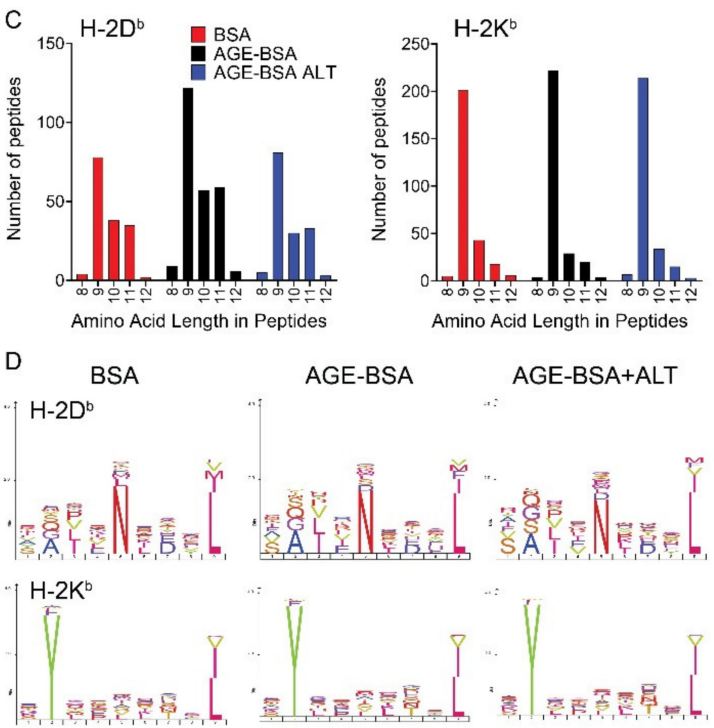

$\mathrm{F}$

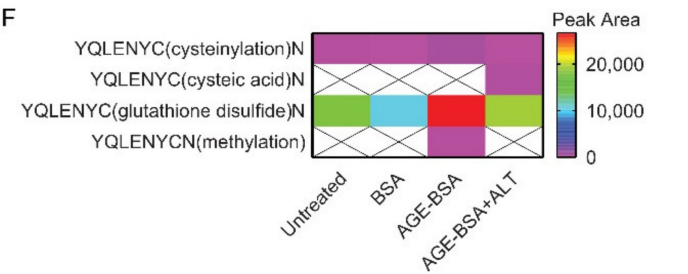

Figure 4. Immunopeptidomic and whole-cell proteomic characterisation of murine NOD $\beta$-cells. NODShiLt derived MIN6N8 $\beta$-cells were treated overnight with unmodified BSA (BSA; $100 \mu \mathrm{g} / \mathrm{mL}$ ), AGE-modified BSA (AGE-BSA; $100 \mu \mathrm{g} / \mathrm{mL}$ ), with or without alagebrium chloride (AGE-BSA+ALT; $40 \mu \mathrm{M}$ ) or untreated, with ALT vehicle control (PBS) or with BSA+ALT (Figures S7 and S8). Pooled cells (total $2 \times 10^{7}$ cells, pooled from $n=4175 \mathrm{~cm}^{2}$ tissue culture flasks) from each treatment were lysed and antibodies against MHC Class $1 \mathrm{a} \mathrm{H}-2 \mathrm{~K}^{\mathrm{b}}$ (clone sf1.1.10) and H-2 $\mathrm{D}^{\mathrm{b}}$ (clone 28.14.8 s) used to capture and identify presented peptides. Peptide complexes were run on RP-HPLC and identified via LC-MS/MS. Schematic of (A) immunopeptidomic and (B) whole-cell proteomic workflow used. (C) Number and length of MHC Class 1a H-2D $\mathrm{D}^{\mathrm{b}}$ (left) and $\mathrm{H}-2 \mathrm{~K}^{\mathrm{b}}$ (right) captured peptides isolated from BSA (red), AGE-BSA (black) and AGE-BSA+ALT (blue) treated MIN6N8 cells. (D) MHC Class Ia bound amino acid motifs of $\mathrm{H}-2 \mathrm{D}^{\mathrm{b}}$ (top) and $\mathrm{H}-2 \mathrm{~K}^{\mathrm{b}}$ (bottom) peptides isolated. (E) Number of common $\mathrm{H}-2 \mathrm{D}^{\mathrm{b}}$ (green; left) and $\mathrm{H}-2 \mathrm{~K}^{\mathrm{b}}$ (purple; right) immunocaptured MHC Class Ia associated peptides. (F) Modifications of insulin peptides precipitated with MHC Class Ia H-2D ${ }^{b}$ antibody from MIN6N8 cells. Scale bar shows peak area.

Next, we assessed if ALT affected the proteome of the same MIN6N8 cells from which cell surface pMHC-I complexes were isolated (Figure 4B). Gene Ontology analyses of MIN6N8 $\beta$-cells cultured in a high AGE environment alone, demonstrated an enrichment in proteins associated with catabolic processes, the immune system and cell cycling compared with BSA (Figure 5A). A high AGE environment enriched for predominately Carboxypeptidase N (Cpn1; Figure 5B; left) and Tubulin isoforms (Tubb; Figure 5B; middle). With the addition of ALT, Tubulin isoforms (Tubb; Figure 5B; middle) and proteins involved in catabolic processes in particular Multivesicular body subunit (Mvb12a), Cysteine protease (Atg4b), Calcium-independent phospholipase (Pnpla8), Carboxypeptidase N (Cpn1) and DNA damage binding protein 1 (DDB1)- and Cullin 4 (CUL4)-associated factor 11 (Dcaf11) were reduced, similar to that of the BSA control (Figure 5B; left). Conversely endocytotic proteins (Figure S8) Calnexin ( $\mathrm{Cnx}$ ) and Progranulin (Grn) were enriched (Figure 5B; right) after ALT therapy. 
A

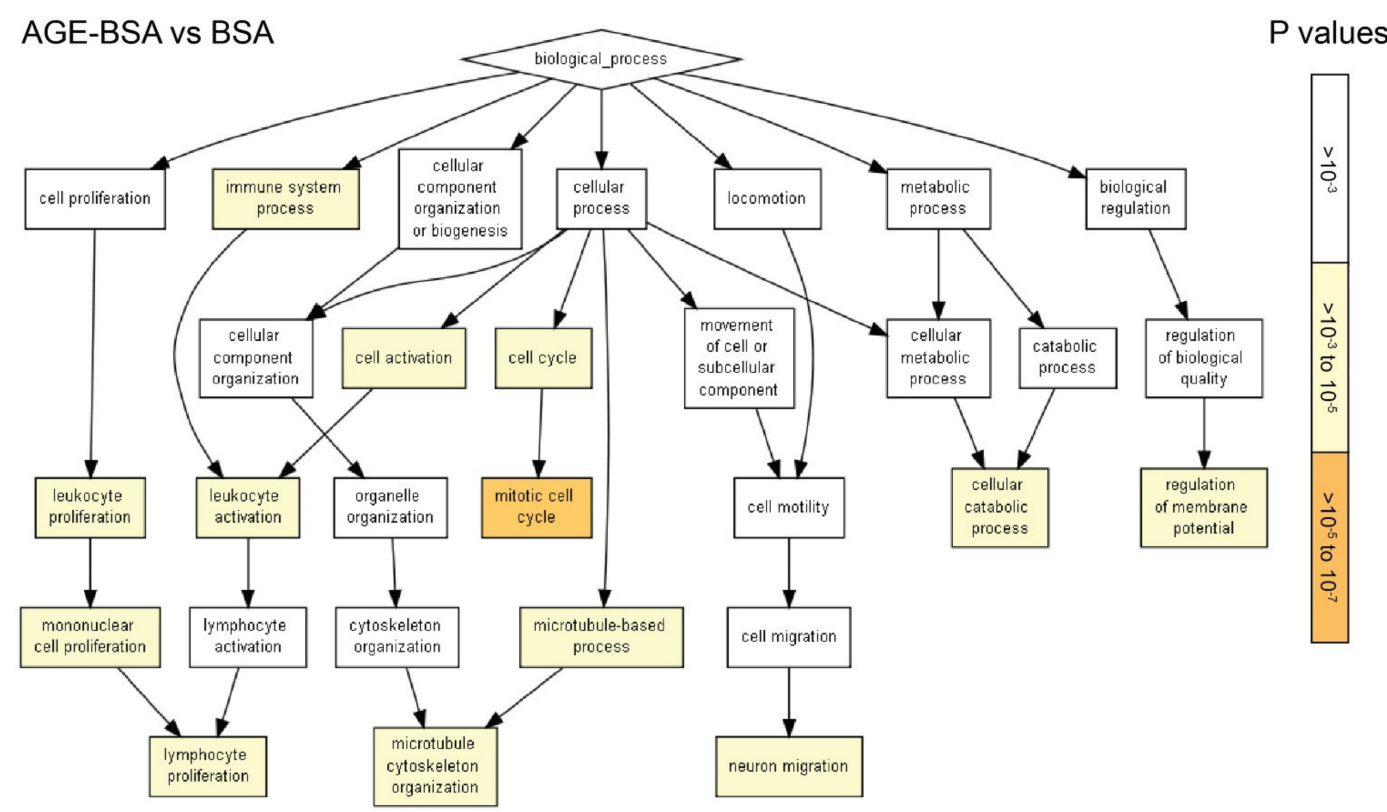

B

Catabolic Processes

Change
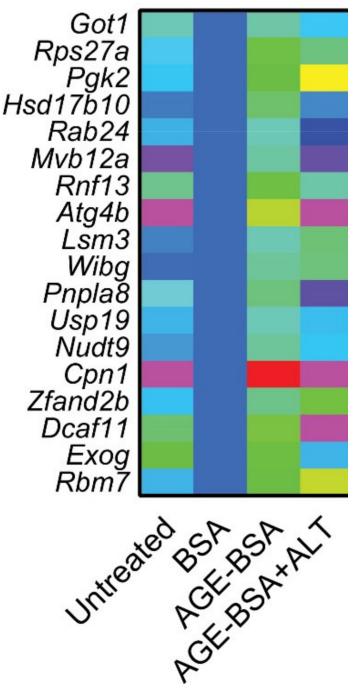

Fold

Mitotic Cell Cycle

Fold Change
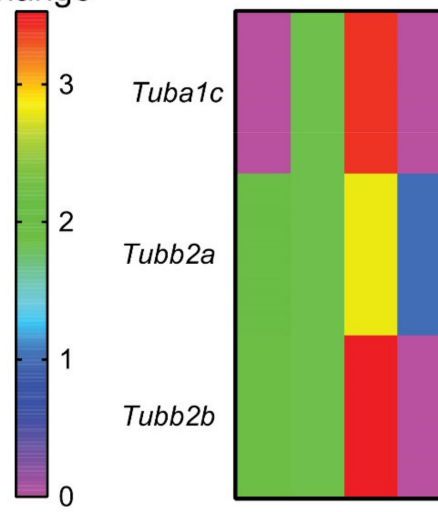

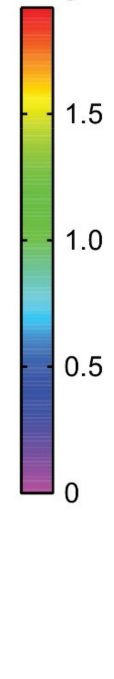

Presynaptic Endocytosis

Fold Change

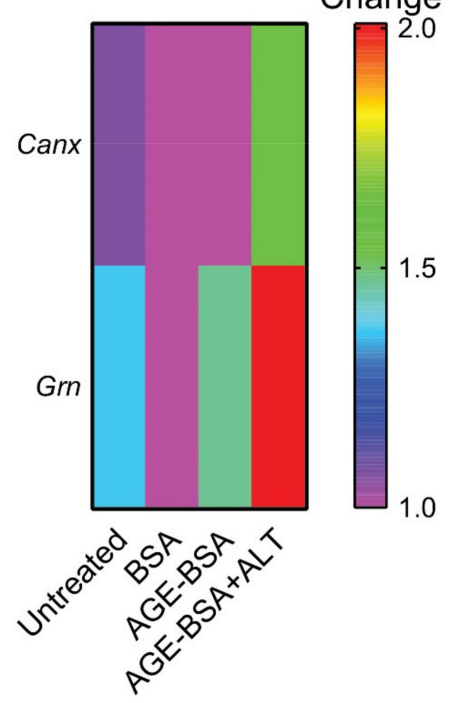

Figure 5. Gene Ontology enrichment analysis of biological processes in peptides isolated from MIN6N8 NOD derived beta cells. NODShiLt derived MIN6N8 beta cells were treated overnight with unmodified (BSA; $100 \mu \mathrm{g} / \mathrm{mL}$ ), AGEmodified BSA (AGE-BSA; $100 \mu \mathrm{g} / \mathrm{mL}$ ) without or with alagebrium chloride (AGE-BSA+ALT; $40 \mu \mathrm{M}$ ). The whole-cell proteome was performed on the cell lysate flowthrough that did not bind to MHC Class 1a antibodies. The effluents were trypsinised, peptides labelled with TMT using different isotypes and identified using LC-MS/MS. Workflow for proteomics is represented in Figure 4B. (A) Pathway analysis of peptides enriched following AGE-BSA vs. BSA treated MIN6N8 cells. $p$ values (right; $10^{-3}$ to $10^{-7}$ ) shown in white-orange scale. (B) Heatmaps of proteins associated with three major enriched Gene Ontology pathways after AGE-BSA and AGE-BSA+ALT vs. control (BSA) MIN6N8 treated cells. Scale shows fold change.

\section{Discussion}

The present study demonstrates that short-term ALT therapy given to NODShitLt mice prior to overt disease onset and then withdrawn, does not impact systemic immune 
cell function or diabetes incidence, but has transient effects on $\beta$-cell function. We observed an increase in insulin secretion during glucose tolerance tests performed halfway through the ALT therapeutic period ( day 75 of life). In addition, the first phase insulin response and action during the first 15 min of the IPGTT were higher in ALT treated mice. Increases in fasted insulin as compared with control mice also persisted until one week after ALT therapy cessation. It is clear however, that these effects on $\beta$-cell function were not sufficient to arrest the development of autoimmune diabetes in ALT treated mice after withdrawal of ALT, suggesting that these $\beta$-cell effects were transient. Blood glucose concentrations were increased during oral but not intraperitoneal glucose challenges at day 75 with ALT therapy. The reasons for this remain to be ascertained in the present study. Further supporting an effect on $\beta$-cells with ALT, were experiments where pre-treatment of NOD recipients delayed diabetes development and lowered blood glucose concentrations overtime following adoptive transfer of G9C8 CD8 TCR transgenic cytotoxic lymphocytes. Circulating glucose concentrations are impacted by various pathways which are impaired in NOD mice. These include changes in peripheral insulin sensitivity [31], hypoglycaemiaglucagon feedback loops, gastric emptying, glucose intestinal absorption and the incretin effect [32]. Certainly, the higher insulin concentrations and insulin:glucose ratios suggest that peripheral insulin sensitivity may be lower in NOD mice treated with ALT as compared with control at day 75 of life. Generally AGE lowering interventions have improved insulin sensitivity in humans who are obese [33] or with type 2 diabetes [34]. However, NOD mice prediabetes often show variable insulin sensitivity which is significantly impacted by the loss of insulin secretion and so it is difficult to ascertain in the present study whether the effects of ALT on insulin, are beneficial. This may be remedied by the determination of Cpeptide during OGTT which would provide specific evidence for effects on insulin secretion per se without being confounded by changes in insulin sensitivity. Indeed, retention of circulating C-peptide concentrations is the most common primary end-point for clinical trials in T1D treatment and prevention [35].

Gastric emptying appears to change during disease development in NOD mice and is accelerated at diabetes onset [36], however in humans, blood glucose elevations in individuals with T1D can slow gastric emptying $[37,38]$ impacting gastrointestinal glucose absorption [39]. Glucagon-like peptide-1 (GLP-1) and gastric inhibitory polypeptide expression in the gut of NOD mice appear unchanged by hyperglycaemia [40], and although combinatory therapies with GLP-1 receptor agonists in individuals with T1D have the potential to enhance $\beta$-cell function [41], recent Phase III trials (NCT01836523, NCT02098395) have observed elevations in hypoglycaemia and hyperglycaemia with ketosis [42,43]. One explanation for a rise in glucose concentrations after the OGTT may be that production of proinsulin is contributing to overall increases in insulin at day 75 and to the end of the ALT treatment period, but limited plasma volumes throughout GTTs, prevented proinsulin from being measured. Together with the relationship between insulin secretion and lack of efficacy on progression to diabetes, our study suggests that upon removal of ALT therapy prediabetes, benefits on $\beta$-cell function are unlikely to be maintained. This therapy if given prophylactically may be best suited during the neonatal period where priming of the immune system against $\beta$-cell antigens like proinsulin [44,45] and GAD65 [45] is key in NOD mice [44] and at-risk children [45].

The reduction in insulitis observed was confirmed using flow cytometry where CD45.1 $1^{+}$cells were reduced in pancreatic digests. Here, lower proportions of $\mathrm{CD}^{+} \mathrm{T}$ cells, B cells and F4/80 ${ }^{+}$macrophages and higher proportions of activated $\mathrm{F} 4 / 80^{+} \mathrm{I}-\mathrm{Ag} 7^{+}$ macrophages were seen. One major limitation of this work was the inability to track temporal changes to immune cells during and after ALT therapy and the inability to examine if ALT therapy impacted the expression of the cell surface receptor for AGEs, RAGE. It would be of interest to understand whether this therapy directly impacts RAGE expression on CD45.1 $1^{+}$lymphocytes locally within the pancreas. Although there is disparity as to whether ALT can mediate effects directly through RAGE, this is suggested in diabetes complications [46,47] and RAGE knockout [48-50] mouse models. Further, studies by 
our team [22] and others [51] show that inhibiting RAGE by prophylactic soluble RAGE (sRAGE) therapy, a decoy receptor that clears circulating AGEs, elevates numbers of RAGE ${ }^{+}$ CD4 and CD8 T cells, $\mathrm{T}_{\text {reg }}$ cells, DCs and macrophages in lymphoid tissue and improves Treg function [22] and prevents the transfer of diabetes by diabetogenic $\mathrm{T}$ cells in NODscid mice [51]. With administration of ALT prediabetes, we saw no effect on IFN- $\gamma$ production of OVA-stimulated splenocytes after 30 days of therapy. The lack of effect on systemic immune cell function within lymphocyte populations was further evidenced by the lack of effect of ALT-treatment of NOD donor splenocytes on diabetes incidence following adoptive transfer to NODscid recipients.

Using an in vitro approach, we examined the MIN6N8 $\beta$-cell immunopeptidome; the peptide repertoire presented by MHC class Ia. The addition of ALT did not change the length of peptides recovered, which were a standard 8-12 amino acids in length as expected [52], but may have impacted their abundance, while motifs were shared amongst all treatment groups. To our knowledge, this is the first time that the immunopeptidome approach has been used to study MHC Class I peptide expression in the NOD derived MIN6N8 mouse $\beta$-cell line after AGE-lowering therapy. Although our work shows preliminary analysis and no major changes to the nature of MHC-I bound peptides, it was interesting to observe the increase of 8-mer YQLENYC(glutathione disulfide)N (InsA ${ }_{14-21}$ ) after AGE-BSA which was reduced after ALT therapy to levels similar to similar to that of BSA control. Mannering et al., previously described post-translational modifications to cysteine residues of a human insulin A-chain T cell epitope [53], and using clustered regularly interspaced short palindromic repeats (CRISPR)/Cas9 to replace murine insulin 1 with human insulin in the NOD mouse, largely protected from diabetes development [54]. The modification of glutathionylation to insulin A should be investigated further beyond this study due the abundance of glutathionylation to cysteines under oxidative stress [55].

Proteomic analysis revealed an enrichment of selected proteins after the addition of AGE-modified BSA compared to unmodified BSA. From our preliminary experiment in MIN6N8 cells, we observed upregulation in tubulin proteins which was not seen in MIN6N8 cells treated with ALT. Microtubules are critical in glucose stimulated insulin secretion [56], regulating the availability of insulin [57] and allowing the travel of insulin granules along tubulin tracks [58]. Upon microtubule destabilisation, a subset of insulin granules are released [59]. High AGE environments consistently reduce the ability of $\beta$ cells to secrete insulin which has been attributed to an increase in oxidative stress $[11,13,16]$. What would be interesting to substantiate in the future, is if high AGE environments result in changes or depolymerisation [14] or hyper-stabilization of the dense microtubular structure in the $\beta$-cell, resulting in insulin secretory dysfunction $[59,60]$.

Proteomic analysis further revealed that ALT therapy enriched for calnexin and progranulin, but reduced multivesicular body subunit and cysteine protease, proteins involved in secretory [61] and autophagy [62-64] pathways, respectively. Calnexin is a lectin chaperone protein in the endoplasmic reticulum (ER), responsible for the folding of $\mathrm{N}$-glycosylated proteins destined for the plasma membrane [61]. ER stress is a major contributor of $\beta$-cell fragility in autoimmune diabetes [65], and while other ER chaperone proteins are reported in the removal of mis-folded proteins [66], to our knowledge, the importance of calnexin in the $\beta$-cell has yet to be determined. Interestingly, ER stress can increase in response to progranulin administration [67] and impair insulin sensitivity in rodent models $[67,68]$. Within the pancreas of MEN1 transgenic mice, progranulin was found to be a potent stimulator of $\beta$-cell proliferation in pancreatic tumours [69] and in $\mathrm{Grn}^{-1-}$ mice, progranulin is vital for endolysosomal trafficking regulation [70]. Interestingly, while $\beta$-cells are high secretory cells like neurons, the role progranulins play in insulin secretion or $\beta$-cell survival is unknown.

Multivesicular body subunit forms a component of the regulatory complex that traffics ubiquinated cargos into multivesicular bodies [62,63], while cysteine protease is required for deconjugation where proteins are cleaved prior to the conjugation to phospholipids [64]. Receptor-mediated endocytosis is an important mechanism in both AGE uptake and 
removal [3], and in the recapture of exocytotic vesicles after insulin release in $\beta$-cells [71]. Although this is an interesting finding, conclusions on the mode of action within $\beta$-cells cannot be made. One exciting application that could further scrutinize the effect of ALT on islet cell secretion would be the rapidly developing methods that can monitor live, single vesicle fusion via two-photon microscopy [72].

Calcium-independent phospholipase hydrolyses ester bonds in phospholipids to release free fatty acids and lysophospholipids [73]. Arachidonic acid is a product generated from this reaction and can be further metabolised into proinflammatory lipid mediators. Within $\beta$-cells, calcium-independent phospholipase appears to be involved in glucose stimulated insulin secretion [74,75], proliferation and apoptosis in INS-1 cells [75] and human islets [76] and has thus been suggested as a target to improve $\beta$-cell longevity [76].

Carboxypeptidase N (Cpn1) is a circulating zinc metalloprotease which cleaves carboxyterminal lysines and arginines from peptides found in the bloodstream [77]. Specific roles of carboxypeptidases have been difficult to ascertain due to the large number of protein members within the CPN family [77]. Within the islet, carboxypeptidase B1 has been shown to regulate rodent $\beta$-cell proliferation [78], carboxypeptidase $E$ is regulated by insulin and is involved in proinsulin processing [79], carboxypeptidase $\mathrm{H}$ and $\mathrm{E}$ has been suggested as a T1D autoantibody in humans [80]. While the inhibition of carboxypeptidase $\mathrm{M}$ in rats reverses insulin resistance [81], and cross-talk between carboxypeptidase $\mathrm{N}$ and Carboxypeptidase B2 is observed during complement activation [82], the functional relevance of the downregulation of this protein with ALT is unknown.

DDB1- and CUL4-associated factors (DCAF) are proteins involved in substrate specificity for protein ubiquitination in the CUL4-DDB1 ubiquitin ligase [83]. While this ligase regulates cellular proliferation, survival and genomic integrity, DCAF11, which was downregulated by ALT therapy, has an unknown function and cellular binding partner, like most identified DCAFs [83].

Given activation of catabolic processes can be an indication of nutrient scarcity [84], the reduction of these catabolic processes by ALT therapy appear strange without the reduction of circulating blood glucose. Still, it would be interesting to understand whether ALT, which reduced subunit proteins involved in endocytic [48,49] and autophagy vesicle formation [62-64], has the ability to confer stress-resistance via the change in metabolic pathways associated with catabolism; fatty acid oxidation and oxidative phosphorylation [84].

The major limitation of our omic work is the lack of technical replicates and the ability to perform dose escalation studies. This is due to the vast number of cells required for immunopeptide precipitation and capture and the slow growth of MIN6N8 cells. Our results were from pooled replicates using previously optimised concentrations and should be interpreted with as such, however, are consistent with the functional studies that suggest a $\beta$-cell effect of ALT treatment rather than an immune mediated effect. This further emphasizes the requirement for future omic experiments in treated preclinical and ex vivo human islets using escalating doses of ALT to validate the effect of AGEs on the protein pathways enriched. Future studies should focus on validation of differentially expressed proteins and pathways using orthogonal validation techniques, such as multiplexed Western blotting and targeted mass spectrometry. We suggest that our database of immunopeptides and proteins (PXD025998) start as a reference point for researchers interested in therapeutic agents of advanced glycation, and its associated receptors and pancreatic islets.

Another limitation of this work is that the specific mode of action of ALT continues to remain elusive. Although first thought as a chemical cross-link breaker of $\alpha$-dicarbonylcontaining compounds, evidence supporting this is lacking and the most likely mechanisms of action include metal chelation, anti-oxidant activity and bypassing the generation of MGO, previously reviewed in [85-87]. Certainly, we observed that circulating AGE precursors, MGO, GO and 3-DG and AGEs CML, CEL and MG-H1 were not decreased directly after cessation of ALT therapy. This may point to the therapeutic dose and exposure time to ALT, the limited number of measurements performed in mice, or simply that the reduction of intermediates or AGEs is localised to the $\beta$-cell, islet, or pancreas. AGE 
precursors and AGEs were not measured within islets in our study and is a clear limitation which should be prioritised in future studies [86]. The time dependency of ALT is however supported by our previous study, in which long-term prophylactic ALT therapy delayed diabetes onset [11]. It has been highlighted by this experimental work and by others [41], that one therapy is unlikely to be effective for T1D prevention. Rather, future work should focus on innovative, combinatorial approaches that could slow $\beta$-cell demise and reduce, reset and/or correct immune system function to prolong diabetes remission [41].

Taken together, these studies present a case for future work to be performed to better understand the effects of AGE lowering therapies on $\beta$-cell function and how these may be temporally determined. Certainly, the AGE-RAGE axis is gaining increasing attention as a potential pathway which can be modulated to both preserve $\beta$-cell function and arrest the development of T1D. However, our present findings suggest that prophylactic therapy, with the AGE lowering therapy, alagebrium chloride prediabetes, is not sufficiently effective in this context and other approaches should be prioritised.

\section{Materials and Methods}

\subsection{Rodent Studies}

Animal experiments were approved by an animal ethics committee (University of Queensland) and adhered to national guidelines by the National Health and Medical Research Council, Australia. Sample size calculations were estimated using a power of 0.80 and $\alpha=0.05$, where $80 \%$ of control mice were expected to develop diabetes by study end from previous studies in the animal facilities. Female NODShiLt mice were housed in the Biological Resource Facility in pathogen-free conditions at the Translational Research Institute, Brisbane Australia, and were randomly assigned to cages $(n=5 /$ cage) and investigators were not blinded to treatments. Mice were given standard chow and water ad libitum, paper bedding and enrichment, and maintained on 12-h light-dark cycles, handled equally and allowed to acclimatise in the facility for at least 7 days prior to the start of procedures. Body weights and non-fasted blood glucose measurements by a glucometer (SensoCard) were taken weekly until day 100 of life, where measurements increased in frequency to at least twice weekly, when monitoring for diabetes incidence.

For diabetes incidence studies, groups of female NOD mice $(n=18-20 /$ group) were either given no treatment or daily, subcutaneous injections of ALT chloride $(1 \mathrm{mg} / \mathrm{kg} /$ day; Anthem Biosciences Ltd., Bangalore, Karnataka, India) for 50 days from day 50 to 100 of life. These mice were followed until diabetes was diagnosed (two consecutive, nonfasting blood glucose measurements of $\geq 15 \mathrm{~m} \cdot \mathrm{mol} / \mathrm{L}$ ) or until day 250 of life in the absence of diabetes. To determine the effect of ALT prediabetes, groups of female NOD mice ( $n=10$ /group) were either given no treatment or daily, subcutaneous injections of ALT chloride ( $1 \mathrm{mg} / \mathrm{kg} /$ day; Anthem Biosciences Ltd.) for up to 40 days from day 50 of life, and were sacrificed from day 80-90 of life. To study effects on pancreatic islets, pancreatic infiltrate and splenocyte function, female NODShiLt mice were randomised ( $n=8$ /group) to receive no treatment or subcutaneous injections of ALT $(1 \mathrm{mg} / \mathrm{kg} /$ day; Anthem Biosciences Ltd.) for 28-32 days from day 50 of life.

Adoptive transfer studies involved either the treatment of female donor or recipient NODShiLt mice ( $n=5-10$ /group) with or without subcutaneous injections of ALT $(1 \mathrm{mg} / \mathrm{kg} /$ day; Anthem Biosciences Ltd.). Either treated or untreated NOD splenocytes were pooled and injected intravenously $\left(1 \times 10^{6}-2 \times 10^{7}\right.$ cells /mouse $)$ into 6-week old NOD.CB17-Prkdcscid/J recipient mice or NOD G9C8 cytotoxic T lymphocytes [30] were activated using recombinant insulin B15-23 peptide, and injected intravenously into 80- dayold-treated NODShiLt recipients [88]. Recipient mice were followed until diabetes diagnosis as described above or until day 250 of life in the absence of diabetes. At the end of the study or experiment end, mice were fasted and anesthetized as previously described [89]. 


\subsection{MIN6N8 Cells}

MIN6N8 cells (kindly provided by Professor Jun-ichi Miyazaki, Osaka University) were maintained in phenol-red free DMEM (ThermoFisher Scientific, Scoresby, VIC, Australia) containing $25 \mathrm{mM}$ glucose (Sigma-Aldrich, Castle Hill, NSW, Australia), 10\% v/v heat-inactivated FBS (ThermoFisher Scientific), $100 \mathrm{U} / \mathrm{mL}$ of penicillin, $100 \mu \mathrm{g} / \mathrm{mL}$ of streptomycin (ThermoFisher Scientific), $2 \mathrm{mM} \cdot \mathrm{L}$-glutamine and $71.5 \mu \mathrm{M}$ beta mercaptoethanol (Sigma-Aldrich) [60]. Unmodified BSA (control) and AGE modified BSA were produced in-house and described elsewhere [11]. Prior to BSA (100 $\mu \mathrm{g} / \mathrm{mL})$, AGE-BSA $(100 \mu \mathrm{g} / \mathrm{mL})$ and ALT $(40 \mu \mathrm{M})$ experimentation, MIN6N8 cells were cultured overnight in culture medium containing only $2 \% v / v$ heat-inactivated FBS.

\subsection{Proteomic Extraction, Labelling, Detection and Quantification in MIN6N8 Cells}

Refer to Supplementary Methods for full detail.

\subsection{Metabolic and Biochemical Measurements}

Glycated haemoglobin from whole blood was measured spectrophotometrically (Cobas Mira, Roche Diagnostics, Sydney, Australia) using a commercial ELISA (Crystal Chem Inc., Downers Grove, IL, USA). From fasting plasma, total insulin (Merck Millipore, Bayswater, VIC, Australia) and proinsulin (Mercodia AB, Uppsala, Sweden) were determined using commercial ELISAs following the manufacturer's instructions. From nonfasting plasma, circulating AGEs and $\alpha$-dicarbonyls were measured using an LC-MS/MS technique as described previously [33].

\subsection{Histology and Immunohistochemistry}

The tail/body of pancreata from NOD mice were fixed ( $10 \%$ neutral buffered formalin), dehydrated and embedded in paraffin using standard techniques. For insulitis, serial sections ( $n=4-8 /$ mouse, $96 \mu \mathrm{m}$ apart) were stained using haematoxylin and eosin and quantified in a blinded fashion (26-88 islets/mouse, $n=4-8$ mice/group), as previously described [90]. Serial sections $(n=2-4 /$ mouse, $96 \mu \mathrm{m}$ apart) were stained using antiinsulin (R\&D systems, Noble Park North, VIC, Australia; clone 182410) or anti-proinsulin (R\&D systems; clone 253627) as previously described [17]. Sections were imaged using an automatic slide scanner (Olympus VS120, Olympus Australia Pty Ltd., Macquarie Park, NSW, Australia). Islet area and number were quantified in a blinded fashion using Visiopharm image analysis software v4.5.6.440 (Olympus Australia Pty Ltd.). Antigen quantification from $\mathrm{DAB}^{+}$areas was calculated as a reciprocal DAB intensity as detailed previously [91].

\subsection{Flow Cytometry}

Pancreata were isolated and digested to obtain single cell suspensions as previously described [92]. Antibodies against CD45.1 (A20), CD4 (GK1.5), CD8 $\alpha$ (53-6.7), CD11b (M1/70), Cd11c (N418) and IA ${ }^{\mathrm{g} 7}$ (10.2.16) were purchased from Biolegend (San Diego, CA, USA). Antibodies against CD19 (ID3), CD45R (RA3-6B2) and IgM (II/41) were purchased from BD Biosciences (North Ryde, NSW, Australia). Antibodies against F4/80 (CI:A3-1) were purchased from AbD Serotec (Raleigh, NC, USA). Pancreatic cells were stained as previously detailed [92] and cytometric data were acquired in an unblinded fashion on the BD LSR II (BD Biosciences) and analysed using FlowJo software v8.

\subsection{ELISpot Assay}

Isolated splenocytes $\left(5 \times 10^{5}\right.$ cells/well) were loaded into polyvinylidene difluoride ELISpot plates (Merck Millipore) which were pre-absorbed with IFN- $\gamma$ antibody. Cells were stimulated with anti-CD3 $(0.1 \mu \mathrm{g} / \mathrm{mL})$ and maintained for $48 \mathrm{~h}$ in RPMI, $5 \% v / v$ FBS, $2 \mathrm{mM}$ of penicillin/streptomycin/glutamine (ThermoFisher Scientific), $50 \mathrm{nM}$ beta mercaptoethanol and $1 \mathrm{mM}$ sodium pyruvate (ThermoFisher Scientific). ELISpot assays 
were developed as previously described [25] using an immune-spot plate reader (AID $\mathrm{GmbH}$, Strassburg, Germany).

\subsection{Statistical Analyses}

Data was analysed for normality by either the D'Agostino-Pearson test, Shapiro-Wilk test or by viewing histograms. Gaussian distributed data are expressed as mean \pm S.D and analysed using the unpaired Student's t-test. Non-Gaussian distributed data are reported as medians with IQR and analysed by the Mann-Whitney U test, or mixed-effects model with Sidak's post-hoc test. Correlations were analysed via linear regression and Pearson's correlation test. Kaplan-Meier survival curves were compared by the Log-Rank test. Predicted variables associated with survival analysis were analysed via Cox regression. Frequency distributions were evaluated by chi-squared $\left(\chi^{2}\right)$. Calculations were performed using graph prism (v6.05 or v8.0.1). $p$ values $<0.05$ were considered statistically significant.

\section{Conclusions}

Overall, our data demonstrates that short duration of ALT therapy does not extend $\beta$-cell function, inhibit experimental autoimmune diabetes or effect systemic immune function. Future studies should dissect whether co-administration of immunomodulatory therapies with ALT during the neonatal period can have an additive protective effect and what cellular processes are changed in response to ALT in islets at the single cell level using sophisticated microscopic and omic approaches.

Supplementary Materials: The following are available online at https:/ /www.mdpi.com/article/ 10.3390/metabo11070426/s1, Figure S1: ALT treatment increases insulin in response to glucose loads, Figure S2: Circulating advanced glycation end products and dicarbonyl compounds (AGE precursors) do not change throughout short-term ALT therapy but associate positively with glycated haemoglobin, Figure S3: Gating strategy for flow cytometry analysis, Figure S4: T and B cell numbers and proportions do not differ after ALT therapy in pLN, Figure S5: Conventional dendritic cell and plasmacytoid dendritic cell numbers and proportions do not differ after ALT in the pLN and spleen, Figure S6: T and B cell numbers and proportions do not differ after ALT therapy in the spleen, Figure S7: Immunopeptidomic characterisation of murine NOD beta cells, Figure S8: GO Pathway Mapping of BSA vs. AGE-BSA+ALT treated MIN6N8 cells, Table S1: $\mathrm{K}^{\mathrm{b}}$ identified peptides list, Table S2: $\mathrm{D}^{\mathrm{b}}$ identified peptides list, Table S3: $\mathrm{D}^{\mathrm{b}}$ identified peptides list; proteins discovered in proteomic discovery, Supplementary Methods: Glucose and insulin tolerance tests, Flow $\mathrm{Cy}-$ tometry (spleen, pancreatic lymph node), Purification of MHC-peptide complexes, Identification of MHC-bound peptides using LC-MS/MS, Trypsin digestion of MIN6N8 lysates for proteomic characterization, TMT-labelling of tryptic peptides; Data Availability Statement.

Author Contributions: Conceptualization, D.J.B., A.W.P., R.S. and J.M.F.; methodology, D.J.B., D.B., N.L.D., C.G.S., R.S., A.W.P., J.M.F.; validation, D.J.B., P.R., C.G.S., R.S., A.W.P., J.M.F.; formal analysis, D.J.B., P.F., R.S., J.M.F.; investigation, D.J.B., P.F., K.L.G., P.R., A.K.F., D.A.M., S.L., M.S.W., B.E.H., R.A., J.L.S., N.L.D., D.B., R.S.; resources, C.G.S., R.S., A.W.P., J.M.F.; data curation, D.J.B., P.F., A.W.P., J.M.F.; writing—original draft preparation, D.J.B.; writing—review and editing, D.J.B., P.F., K.L.G., A.K.F., R.S., A.W.P., J.M.F.; visualization, D.J.B., P.F., K.L.G., P.R.; supervision, C.G.S., R.S., A.W.P., J.M.F.; project administration, D.J.B.; funding acquisition, C.G.S., R.S., A.W.P., J.M.F. All authors have read and agreed to the published version of the manuscript.

Funding: This was funded by the National Health and Medical Research Council of Australia (NHMRC; 1023664, 1165490, 1084283, 1043315 J.M.F., R.S., A.W.P.), the Victorian Government Infrastructure Program, and the Mater Foundation. Authors were specifically supported by: Mater Foundation (D.J.B.), Victorian Department of Health and Human Services acting through the Victorian Cancer Agency (P.F.), Australian Postgraduate Award Scholarship (P.R., A.K.F.), NHMRC Project Grant (1023664; D.M., J.M.F.), UQ/JDRF Postgraduate Scholarship (S.L.), JDRF Postdoctoral Fellowship (M.S.W.), NHMRC Peter Doherty Fellowship (B.E.H.), NHMRC Project Grant (1165490, 1084283; K.L.G., R.A.), NHMRC Principal Research Fellowship (1137739; A.W.P.), ARC Fellowship (FT110100372; R.S.) and NHMRC Senior Research Fellowship (1004503, 1102935; J.M.F.). 
Institutional Review Board Statement: The study was conducted according to the guidelines of the NHMRC and approved by the Ethics Committees of the University of Queensland (TRI/MMRI/NHMRC: 169/12; 036/13; 210/15).

Informed Consent Statement: Not applicable.

Data Availability Statement: Availability of the immunopeptidome and proteomic datasets can be found in the PRIDE data repository, accession number: PXD025998, doi:10.6019/PXD025998.

Acknowledgments: The MIN6N8 cell line used for in vitro experiments were kindly provided by Jun-ichi Miyazaki, Osaka University. The TCR $\alpha$ and TCR $\beta$ founder lines used to generate the G9C8 mice were kind gifts from Susan F. Wong, Cardiff University. We would like to acknowledge the staff at the UQ Biological Research Facility, Crystal Chang of the Histology Facility and Sandrine Roy and Ali Ju of the Microscopy Facility, located in the Translational Research Institute. We would like to acknowledge the provision of instrumentation, training, and technical support by the Monash Biomedical Proteomics Facility. Computational resources for omic analysis were supported by the R@CMon/Monash Node of the NeCTAR Research Cloud, an initiative of the Australian Government's Super Science Scheme and the Education Investment Fund. We would like to extend our sincere thanks to Ristan Greer for statistical advice.

Conflicts of Interest: The funders had no role in the design of the study; in the collection, analyses, or interpretation of data; in the writing of the manuscript, or in the decision to publish the results. JMF holds two patents for alagebrium chloride.

\section{References}

1. Monnier, V.M.; Cerami, A. Nonenzymatic browning in vivo: Possible process for aging of long-lived proteins. Science 1981, 211, 491-493. [CrossRef] [PubMed]

2. O'Brien, J.; Morrissey, P.A. Nutritional and toxicological aspects of the Maillard browning reaction in foods. Crit. Rev. Food Sci. Nutr. 1989, 28, 211-248. [CrossRef]

3. Ott, C.; Jacobs, K.; Haucke, E.; Navarrete Santos, A.; Grune, T.; Simm, A. Role of advanced glycation end products in cellular signaling. Redox Biol. 2014, 2, 411-429. [CrossRef]

4. Chavakis, T.; Bierhaus, A.; Al-Fakhri, N.; Schneider, D.; Witte, S.; Linn, T.; Nagashima, M.; Morser, J.; Arnold, B.; Preissner, K.T.; et al. The Pattern Recognition Receptor (RAGE) Is a Counterreceptor for Leukocyte Integrins. Nov. Pathw. Inflamm. Cell Recruit. 2003, 198, 1507-1515. [CrossRef] [PubMed]

5. Demling, N.; Ehrhardt, C.; Kasper, M.; Laue, M.; Knels, L.; Rieber, E.P. Promotion of cell adherence and spreading: A novel function of RAGE, the highly selective differentiation marker of human alveolar epithelial type I cells. Cell Tissue Res. 2006, 323, 475-488. [CrossRef]

6. Schmidt, A.M.; Yan, S.D.; Brett, J.; Mora, R.; Nowygrod, R.; Stern, D. Regulation of human mononuclear phagocyte migration by cell surface-binding proteins for advanced glycation end products. J. Clin. Investig. 1993, 91, 2155-2168. [CrossRef] [PubMed]

7. Manfredi, A.A.; Capobianco, A.; Esposito, A.; De Cobelli, F.; Canu, T.; Monno, A.; Raucci, A.; Sanvito, F.; Doglioni, C.; Nawroth, P.P.; et al. Maturing Dendritic Cells Depend on RAGE for In Vivo Homing to Lymph Nodes. J. Immunol. 2008, 180, $2270-2275$. [CrossRef]

8. Dumitriu, I.E.; Bianchi, M.E.; Bacci, M.; Manfredi, A.A.; Rovere-Querini, P. The secretion of HMGB1 is required for the migration of maturing dendritic cells. J. Leukoc. Biol. 2007, 81, 84-91. [CrossRef]

9. Serban, A.I.; Stanca, L.; Geicu, O.I.; Munteanu, M.C.; Dinischiotu, A. RAGE and TGF- $\beta 1$ Cross-Talk Regulate Extracellular Matrix Turnover and Cytokine Synthesis in AGEs Exposed Fibroblast Cells. PLoS ONE 2016, 11, e0152376. [CrossRef] [PubMed]

10. Beyan, H.; Riese, H.; Hawa, M.I.; Beretta, G.; Davidson, H.W.; Hutton, J.C.; Burger, H.; Schlosser, M.; Snieder, H.; Boehm, B.O.; et al. Glycotoxin and autoantibodies are additive environmentally determined predictors of type 1 diabetes: A twin and population study. Diabetes 2012, 61, 1192-1198. [CrossRef]

11. Coughlan, M.T.; Yap, F.Y.; Tong, D.C.; Andrikopoulos, S.; Gasser, A.; Thallas-Bonke, V.; Webster, D.E.; Miyazaki, J.; Kay, T.W.; Slattery, R.M.; et al. Advanced glycation end products are direct modulators of beta-cell function. Diabetes 2011, 60, 2523-2532. [CrossRef]

12. Salonen, K.M.; Ryhanen, S.J.; Forbes, J.M.; Harkonen, T.; Ilonen, J.; Laine, A.P.; Groop, P.H.; Knip, M.; The Finnish Pediatric Diabetes Register. Circulating concentrations of soluble receptor for AGE are associated with age and AGER gene polymorphisms in children with newly diagnosed type 1 diabetes. Diabetes Care 2014, 37, 1975-1981. [CrossRef]

13. Kong, X.; Wang, G.-D.; Ma, M.-Z.; Deng, R.-Y.; Guo, L.-Q.; Zhang, J.-X.; Yang, J.-R.; Su, Q. Sesamin Ameliorates Advanced Glycation End Products-Induced Pancreatic $\beta$-Cell Dysfunction and Apoptosis. Nutrients 2015, 7, 4689-4704. [CrossRef]

14. You, J.; Wang, Z.; Xu, S.; Zhang, W.; Fang, Q.; Liu, H.; Peng, L.; Deng, T.; Lou, J. Advanced Glycation End Products Impair Glucose-Stimulated Insulin Secretion of a Pancreatic Beta-Cell Line INS-1-3 by Disturbance of Microtubule Cytoskeleton via p38/MAPK Activation. J. Diabetes Res. 2016, 2016, 9073037. [CrossRef] [PubMed] 
15. Shu, T.; Zhu, Y.; Wang, H.; Lin, Y.; Ma, Z.; Han, X. AGEs Decrease Insulin Synthesis in Pancreatic $\beta$-Cell by Repressing Pdx-1 Protein Expression at the Post-Translational Level. PLoS ONE 2011, 6, e18782. [CrossRef] [PubMed]

16. Zhao, Z.; Zhao, C.; Zhang, X.H.; Zheng, F.; Cai, W.; Vlassara, H.; Ma, Z.A. Advanced Glycation End Products Inhibit GlucoseStimulated Insulin Secretion through Nitric Oxide-Dependent Inhibition of Cytochrome c Oxidase and Adenosine Triphosphate Synthesis. Endocrinology 2009, 150, 2569-2576. [CrossRef] [PubMed]

17. Borg, D.J.; Yap, F.Y.T.; Keshvari, S.; Simmons, D.G.; Gallo, L.A.; Fotheringham, A.K.; Zhuang, A.; Slattery, R.M.; Hasnain, S.Z.; Coughlan, M.T.; et al. Perinatal exposure to high dietary advanced glycation end products in transgenic NOD8.3 mice leads to pancreatic beta cell dysfunction. Islets 2018, 10, 10-24. [CrossRef]

18. Peppa, M.; He, C.; Hattori, M.; McEvoy, R.; Zheng, F.; Vlassara, H. Fetal or Neonatal Low-Glycotoxin Environment Prevents Autoimmune Diabetes in NOD Mice. Diabetes 2003, 52, 1441-1448. [CrossRef] [PubMed]

19. Forbes, J.M.; Cowan, S.P.; Andrikopoulos, S.; Morley, A.L.; Ward, L.C.; Walker, K.Z.; Cooper, M.E.; Coughlan, M.T. Glucose homeostasis can be differentially modulated by varying individual components of a western diet. J. Nutr. Biochem. 2013, 24, 1251-1257. [CrossRef] [PubMed]

20. Pearson, J.A.; Wong, F.S.; Wen, L. The importance of the Non Obese Diabetic (NOD) mouse model in autoimmune diabetes. J. Autoimmun. 2016, 66, 76-88. [CrossRef]

21. Forbes, J.M.; Soderlund, J.; Yap, F.Y.; Knip, M.; Andrikopoulos, S.; Ilonen, J.; Simell, O.; Veijola, R.; Sourris, K.C.; Coughlan, M.T.; et al. Receptor for advanced glycation end-products (RAGE) provides a link between genetic susceptibility and environmental factors in type 1 diabetes. Diabetologia 2011, 54, 1032-1042. [CrossRef]

22. Leung, S.S.; Borg, D.J.; McCarthy, D.A.; Boursalian, T.E.; Cracraft, J.; Zhuang, A.; Fotheringham, A.K.; Flemming, N.; Watkins, T.; Miles, J.J.; et al. Expansion of Functional Regulatory T Cells Using Soluble RAGE Prevents Type 1 Diabetes. bioRxiv 2020. [CrossRef]

23. Ulrich, P.; Cerami, A. Protein glycation, diabetes, and aging. Recent Prog. Horm. Res. 2001, 56, 1-21. [CrossRef] [PubMed]

24. Kim, T.; Spiegel, D.A. The unique reactivity of N-phenacyl-derived thiazolium salts toward $\alpha$-dicarbonyl compounds. Rejuvenation Res. 2013, 16, 43-50. [CrossRef]

25. Steptoe, R.J.; Ritchie, J.M.; Wilson, N.S.; Villadangos, J.A.; Lew, A.M.; Harrison, L.C. Cognate CD4+ Help Elicited by Resting Dendritic Cells Does Not Impair the Induction of Peripheral Tolerance in CD8+ T Cells. J. Immunol. 2007, 178, $2094-2103$. [CrossRef]

26. Gagnerault, M.-C.; Luan, J.J.; Lotton, C.; Lepault, F. Pancreatic Lymph Nodes Are Required for Priming of $\beta$ Cell Reactive T Cells in NOD Mice. J. Exp. Med. 2002, 196, 369-377. [CrossRef] [PubMed]

27. Jaakkola, I.; Jalkanen, S.; Hänninen, A. Diabetogenic T cells are primed both in pancreatic and gut-associated lymph nodes in NOD mice. Eur. J. Immunol. 2003, 33, 3255-3264. [CrossRef] [PubMed]

28. Tang, Q.; Henriksen, K.J.; Bi, M.; Finger, E.B.; Szot, G.; Ye, J.; Masteller, E.L.; McDevitt, H.; Bonyhadi, M.; Bluestone, J.A. In Vitro-expanded Antigen-specific Regulatory T Cells Suppress Autoimmune Diabetes. J. Exp. Med. 2004, 199, $1455-1465$. [CrossRef]

29. Viisanen, T.; Gazali, A.M.; Ihantola, E.-L.; Ekman, I.; Näntö-Salonen, K.; Veijola, R.; Toppari, J.; Knip, M.; Ilonen, J.; Kinnunen, T. FOXP3+ Regulatory T Cell Compartment Is Altered in Children With Newly Diagnosed Type 1 Diabetes but Not in AutoantibodyPositive at-Risk Children. Front. Immunol. 2019, 10, 19. [CrossRef]

30. Wong, F.S.; Khai Siew, L.; Scott, G.; Thomas, I.J.; Chapman, S.; Viret, C.; Wen, L. Activation of Insulin-Reactive CD8 T-Cells for Development of Autoimmune Diabetes. Diabetes 2009, 58, 1156. [CrossRef]

31. Chaparro, R.J.; Konigshofer, Y.; Beilhack, G.F.; Shizuru, J.A.; McDevitt, H.O.; Chien, Y.-h. Nonobese diabetic mice express aspects of both type 1 and type 2 diabetes. Proc. Natl. Acad. Sci. USA 2006, 103, 12475. [CrossRef]

32. Alquier, T.; Poitout, V. Considerations and guidelines for mouse metabolic phenotyping in diabetes research. Diabetologia 2018, 61, 526-538. [CrossRef]

33. De Courten, B.; de Courten, M.P.; Soldatos, G.; Dougherty, S.L.; Straznicky, N.; Schlaich, M.; Sourris, K.C.; Chand, V.; Scheijen, J.L.; Kingwell, B.A.; et al. Diet low in advanced glycation end products increases insulin sensitivity in healthy overweight individuals: A double-blind, randomized, crossover trial. Am. J. Clin. Nutr. 2016, 103, 1426-1433. [CrossRef] [PubMed]

34. Uribarri, J.; Cai, W.; Ramdas, M.; Goodman, S.; Pyzik, R.; Chen, X.; Zhu, L.; Striker, G.E.; Vlassara, H. Restriction of Advanced Glycation End Products Improves Insulin Resistance in Human Type 2 Diabetes. Potential Role AGER1 SIRT1 2011, 34, 1610-1616. [CrossRef]

35. Ehlers, M.R. Strategies for clinical trials in type 1 diabetes. J. Autoimmun. 2016, 71, 88-96. [CrossRef]

36. Choi, K.M.; Zhu, J.; Stoltz, G.J.; Vernino, S.; Camilleri, M.; Szurszewski, J.H.; Gibbons, S.J.; Farrugia, G. Determination of gastric emptying in nonobese diabetic mice. Am. J. Physiol. Gastrointest. Liver Physiol. 2007, 293, G1039-G1045. [CrossRef] [PubMed]

37. Fraser, R.J.; Horowitz, M.; Maddox, A.F.; Harding, P.E.; Chatterton, B.E.; Dent, J. Hyperglycaemia slows gastric emptying in type 1 (insulin-dependent) diabetes mellitus. Diabetologia 1990, 33, 675-680. [CrossRef] [PubMed]

38. Schvarcz, E.; Palmer, M.; Aman, J.; Horowitz, M.; Stridsberg, M.; Berne, C. Physiological hyperglycemia slows gastric emptying in normal subjects and patients with insulin-dependent diabetes mellitus. Gastroenterology 1997, 113, 60-66. [CrossRef]

39. Yki-Järvinen, H.; Helve, E.; Koivisto, V.A. Hyperglycemia Decreases Glucose Uptake in Type I Diabetes. Diabetes 1987, $36,892$. [CrossRef] [PubMed] 
40. Berghöfer, P.; Peterson, R.G.; Schneider, K.; Fehmann, H.C.; Göke, B. Incretin hormone expression in the gut of diabetic mice and rats. Metabolism 1997, 46, 261-267. [CrossRef]

41. Von Scholten, B.J.; Kreiner, F.F.; Gough, S.C.L.; von Herrath, M. Current and future therapies for type 1 diabetes. Diabetologia 2021, 64, 1037-1048. [CrossRef] [PubMed]

42. Ahrén, B.; Hirsch, I.B.; Pieber, T.R.; Mathieu, C.; Gómez-Peralta, F.; Hansen, T.K.; Philotheou, A.; Birch, S.; Christiansen, E.; Jensen, T.J.; et al. Efficacy and Safety of Liraglutide Added to Capped Insulin Treatment in Subjects With Type 1 Diabetes: The ADJUNCT TWO Randomized Trial. Diabetes Care 2016, 39, 1693. [CrossRef]

43. Mathieu, C.; Zinman, B.; Hemmingsson, J.U.; Woo, V.; Colman, P.; Christiansen, E.; Linder, M.; Bode, B. Efficacy and Safety of Liraglutide Added to Insulin Treatment in Type 1 Diabetes: The ADJUNCT ONE Treat-To-Target Randomized Trial. Diabetes Care 2016, dc160691. [CrossRef] [PubMed]

44. Jhala, G.; Chee, J.; Trivedi, P.M.; Selck, C.; Gurzov, E.N.; Graham, K.L.; Thomas, H.E.; Kay, T.W.H.; Krishnamurthy, B. Perinatal tolerance to proinsulin is sufficient to prevent autoimmune diabetes. JCI Insight 2016, 1, e86065. [CrossRef]

45. Heninger, A.-K.; Eugster, A.; Kuehn, D.; Buettner, F.; Kuhn, M.; Lindner, A.; Dietz, S.; Jergens, S.; Wilhelm, C.; Beyerlein, A.; et al. A divergent population of autoantigen-responsive CD4+ T cells in infants prior to $\beta$ cell autoimmunity. Sci. Transl. Med. 2017, 9. [CrossRef]

46. Candido, R.; Forbes, J.M.; Thomas, M.C.; Thallas, V.; Dean, R.G. A breaker of advanced glycation end products attenuates diabetes-induced myocardial structural changes. Circ. Res. 2003, 92, 785-792. [CrossRef]

47. Forbes, J.M.; Yee, L.T.L.; Thallas, V.; Lassila, M.; Candido, R. Advanced glycation end product interventions reduce diabetesaccelerated atherosclerosis. Diabetes 2004, 53, 1813-1823. [CrossRef]

48. Harcourt, B.E.; Sourris, K.C.; Coughlan, M.T.; Walker, K.Z.; Dougherty, S.L.; Andrikopoulos, S.; Morley, A.L.; Thallas-Bonke, V.; Chand, V.; Penfold, S.A.; et al. Targeted reduction of advanced glycation improves renal function in obesity. Kidney Int. 2011, 80, 190-198. [CrossRef]

49. Tan, A.L.Y.; Sourris, K.C.; Harcourt, B.E.; Thallas-Bonke, V.; Penfold, S.; Andrikopoulos, S.; Thomas, M.C.; O’Brien, R.C.; Bierhaus, A.; Cooper, M.E.; et al. Disparate effects on renal and oxidative parameters following RAGE deletion, AGE accumulation inhibition, or dietary AGE control in experimental diabetic nephropathy. Am. J. Physiol. Ren. Physiol. 2010, 298, F763-F770. [CrossRef] [PubMed]

50. Tikellis, C.; Thomas, M.C.; Harcourt, B.E.; Coughlan, M.T.; Pete, J.; Bialkowski, K.; Tan, A.; Bierhaus, A.; Cooper, M.E.; Forbes, J.M. Cardiac inflammation associated with a Western diet is mediated via activation of RAGE by AGEs. Am. J. Physiol. Endocrinol. Metab. 2008, 295, E323-E330. [CrossRef]

51. Chen, Y.; Yan, S.S.; Colgan, J.; Zhang, H.-P.; Luban, J.; Schmidt, A.M.; Stern, D.; Herold, K.C. Blockade of Late Stages of Autoimmune Diabetes by Inhibition of the Receptor for Advanced Glycation End Products. J. Immunol. 2004, $173,1399$. [CrossRef]

52. Schuster, H.; Shao, W.; Weiss, T.; Pedrioli, P.G.A.; Roth, P.; Weller, M.; Campbell, D.S.; Deutsch, E.W.; Moritz, R.L.; Planz, O.; et al. A tissue-based draft map of the murine MHC class I immunopeptidome. Sci. Data 2018, 5, 180157. [CrossRef] [PubMed]

53. Mannering, S.I.; Harrison, L.C.; Williamson, N.A.; Morris, J.S.; Thearle, D.J.; Jensen, K.P.; Kay, T.W.H.; Rossjohn, J.; Falk, B.A.; Nepom, G.T.; et al. The insulin A-chain epitope recognized by human T cells is posttranslationally modified. J. Exp. Med. 2005, 202, 1191-1197. [CrossRef]

54. Elso, C.M.; Scott, N.A.; Mariana, L.; Masterman, E.I.; Sutherland, A.P.R.; Thomas, H.E.; Mannering, S.I. Replacing murine insulin 1 with human insulin protects NOD mice from diabetes. PLoS ONE 2019, 14, e0225021. [CrossRef] [PubMed]

55. Forman, H.J. Glutathione-From antioxidant to post-translational modifier. Arch. Biochem. Biophys. 2016, 595, 64-67. [CrossRef]

56. Ho, K.-H.; Yang, X.; Osipovich, A.B.; Cabrera, O.; Hayashi, M.L.; Magnuson, M.A.; Gu, G.; Kaverina, I. Glucose Regulates Microtubule Disassembly and the Dose of Insulin Secretion via Tau Phosphorylation. Diabetes 2020, 69, 1936. [CrossRef] [PubMed]

57. Zhu, X.; Hu, R.; Brissova, M.; Stein, R.W.; Powers, A.C.; Gu, G.; Kaverina, I. Microtubules Negatively Regulate Insulin Secretion in Pancreatic $\beta$ Cells. Dev. Cell 2015, 34, 656-668. [CrossRef]

58. Fu, Z.; Gilbert, E.R.; Liu, D. Regulation of insulin synthesis and secretion and pancreatic Beta-cell dysfunction in diabetes. Curr Diabetes Rev. 2013, 9, 25-53. [CrossRef]

59. Trogden, K.P.; McKinney, H.; Zhu, X.; Arpag, G.; Folland, T.G.; Osipovich, A.B.; Magnuson, M.A.; Zanic, M.; Gu, G.; Holmes, W.R.; et al. Microtubules regulate pancreatic beta cell heterogeneity via spatiotemporal control of insulin secretion hot spots. bioRxiv 2020. [CrossRef]

60. Miyazaki, J.I.; Araki, K.; Yamato, E.; Ikegami, H.; Asano, T.; Shibasaki, Y.; Oka, Y.; Yamamura, K.I. Establishment of a Pancreatic Beta-Cell Line That Retains Glucose-Inducible Insulin-Secretion-Special Reference to Expression of Glucose Transporter Isoforms. Endocrinology 1990, 127, 126-132. [CrossRef] [PubMed]

61. Kozlov, G.; Gehring, K. Calnexin cycle-Structural features of the ER chaperone system. FEBS J. 2020, 287, 4322-4340. [CrossRef] [PubMed]

62. Filimonenko, M.; Stuffers, S.; Raiborg, C.; Yamamoto, A.; Malerød, L.; Fisher, E.M.C.; Isaacs, A.; Brech, A.; Stenmark, H.; Simonsen, A. Functional multivesicular bodies are required for autophagic clearance of protein aggregates associated with neurodegenerative disease. J. Cell Biol. 2007, 179, 485-500. [CrossRef] [PubMed]

63. Piper, R.C.; Katzmann, D.J. Biogenesis and function of multivesicular bodies. Annu. Rev. Cell Dev. Biol. 2007, $23,519-547$. [CrossRef] [PubMed] 
64. Li, M.; Fu, Y.; Yang, Z.; Yin, X.M. Measurement of the Activity of the Atg4 Cysteine Proteases. Methods Enzymol. 2017, 587, 207-225. [CrossRef]

65. Engin, F.; Yermalovich, A.; Nguyen, T.; Hummasti, S.; Fu, W.; Eizirik, D.L.; Mathis, D.; Hotamisligil, G.S. Restoration of the unfolded protein response in pancreatic beta cells protects mice against type 1 diabetes. Sci. Transl. Med. 2013, 5, 211 ra156. [CrossRef]

66. Oyadomari, S.; Takeda, K.; Takiguchi, M.; Gotoh, T.; Matsumoto, M.; Wada, I.; Akira, S.; Araki, E.; Mori, M. Nitric oxide-induced apoptosis in pancreatic beta cells is mediated by the endoplasmic reticulum stress pathway. Proc. Natl. Acad. Sci. USA 2001, 98, 10845-10850. [CrossRef] [PubMed]

67. Li, H.; Zhou, B.; Liu, J.; Li, F.; Li, Y.; Kang, X.; Sun, H.; Wu, S. Administration of progranulin (PGRN) triggers ER stress and impairs insulin sensitivity via PERK-eIF2 $\alpha$-dependent manner. Cell Cycle 2015, 14, 1893-1907. [CrossRef]

68. Matsubara, T.; Mita, A.; Minami, K.; Hosooka, T.; Kitazawa, S.; Takahashi, K.; Tamori, Y.; Yokoi, N.; Watanabe, M.; Matsuo, E.-i.; et al. PGRN is a Key Adipokine Mediating High Fat Diet-Induced Insulin Resistance and Obesity through IL-6 in Adipose Tissue. Cell Metab. 2012, 15, 38-50. [CrossRef]

69. Barbu, A.; Lejonklou, M.H.; Skogseid, B. Progranulin Stimulates Proliferation of Mouse Pancreatic Islet Cells and Is Overexpressed in the Endocrine Pancreatic Tissue of an MEN1 Mouse Model. Pancreas 2016, 45, 533-540. [CrossRef]

70. Arrant, A.E.; Davis, S.E.; Vollmer, R.M.; Murchison, C.F.; Mobley, J.A.; Nana, A.L.; Spina, S.; Grinberg, L.T.; Karydas, A.M.; Miller, B.L.; et al. Elevated levels of extracellular vesicles in progranulin-deficient mice and FTD-GRN Patients. Ann. Clin. Transl. Neurol. 2020, 7, 2433-2449. [CrossRef]

71. MacDonald, P.E.; Rorsman, P. The Ins and Outs of Secretion from Pancreatic $\beta$-Cells: Control of Single-Vesicle Exo- and Endocytosis. Physiology 2007, 22, 113-121. [CrossRef] [PubMed]

72. Tarasov, A.I.; Galvanovskis, J.; Rorsman, O.; Hamilton, A.; Vergari, E.; Johnson, P.R.V.; Reimann, F.; Ashcroft, F.M.; Rorsman, P. Monitoring real-time hormone release kinetics via high-content 3-D imaging of compensatory endocytosis. Lab Chip 2018, 18, 2838-2848. [CrossRef]

73. Akiba, S.; Sato, T. Cellular Function of Calcium-Independent Phospholipase A A $_{2}$ Biol. Pharm. Bull. 2004, 27, 1174-1178. [CrossRef]

74. Caporarello, N.; Salmeri, M.; Scalia, M.; Motta, C.; Parrino, C.; Frittitta, L.; Olivieri, M.; Cristaldi, M.; Avola, R.; Bramanti, V.; et al. Cytosolic and Calcium-Independent Phospholipases A2 Activation and Prostaglandins E2 Are Associated with Escherichia coli-Induced Reduction of Insulin Secretion in INS-1E Cells. PLoS ONE 2016, 11, e0159874. [CrossRef]

75. Ramanadham, S.; Song, H.; Bao, S.; Hsu, F.-F.; Zhang, S.; Ma, Z.; Jin, C.; Turk, J. Islet Complex Lipids. Diabetes 2004, 53, S179. [CrossRef]

76. Lei, X.; Zhang, S.; Bohrer, A.; Barbour, S.E.; Ramanadham, S. Role of calcium-independent phospholipase A(2) $\beta$ in human pancreatic islet $\beta$-cell apoptosis. Am. J. Physiol. Endocrinol. Metab. 2012, 303, E1386-E1395. [CrossRef] [PubMed]

77. Matthews, K.W.; Mueller-Ortiz, S.L.; Wetsel, R.A. Carboxypeptidase N: A pleiotropic regulator of inflammation. Mol. Immunol. 2004, 40, 785-793. [CrossRef] [PubMed]

78. Yu, S.-L.; Han, S.; Kim, H.R.; Park, J.W.; Jin, D.I.; Kang, J. Phosphorylation of carboxypeptidase B1 protein regulates $\beta$-cell proliferation. Int. J. Mol. Med. 2017, 40, 1397-1404. [CrossRef]

79. Liew, C.W.; Assmann, A.; Templin, A.T.; Raum, J.C.; Lipson, K.L.; Rajan, S.; Qiang, G.; Hu, J.; Kawamori, D.; Lindberg, I.; et al. Insulin regulates carboxypeptidase E by modulating translation initiation scaffolding protein eIF4G1 in pancreatic beta cells. Proc. Natl. Acad. Sci. USA 2014, 111, E2319-E2328. [CrossRef]

80. Roep, B.O.; Peakman, M. Antigen targets of type 1 diabetes autoimmunity. Cold Spring Harb. Perspect. Med. 2012,2 , a007781. [CrossRef] [PubMed]

81. Haddad, Y.; Couture, R. Kininase 1 As a Preclinical Therapeutic Target for Kinin B1 Receptor in Insulin Resistance. Front. Pharmacol. 2017, 8, 509. [CrossRef]

82. Leung, L.L.K.; Morser, J. Carboxypeptidase B2 and carboxypeptidase $\mathrm{N}$ in the crosstalk between coagulation, thrombosis, inflammation, and innate immunity. J. Thromb. Haemost. 2018, 16, 1474-1486. [CrossRef]

83. Lee, J.; Zhou, P. DCAFs, the Missing Link of the CUL4-DDB1 Ubiquitin Ligase. Mol. Cell 2007, 26, 775-780. [CrossRef] [PubMed]

84. Wang, A.; Luan, H.H.; Medzhitov, R. An evolutionary perspective on immunometabolism. Science 2019, 363, eaar3932. [CrossRef] [PubMed]

85. Borg, D.J.; Forbes, J.M. Targeting advanced glycation with pharmaceutical agents: Where are we now? Glycoconj. J. 2016, 33, 653-670. [CrossRef]

86. Schalkwijk, C.G.; Stehouwer, C.D.A. Methylglyoxal, a Highly Reactive Dicarbonyl Compound, in Diabetes, Its Vascular Complications, and Other Age-Related Diseases. Physiol. Rev. 2019, 100, 407-461. [CrossRef]

87. Sell, D.R.; Monnier, V.M. Molecular Basis of Arterial Stiffening: Role of Glycation-A Mini-Review. Gerontology 2012, 58, 227-237. [CrossRef] [PubMed]

88. Reeves, P.L.S.; Rudraraju, R.; Liu, X.; Wong, F.S.; Hamilton-Williams, E.E.; Steptoe, R.J. APC-targeted proinsulin expression inactivates insulin-specific memory CD8+ T cells in NOD mice. Immunol. Cell Biol. 2017, 95, 765-774. [CrossRef]

89. Gallo, L.A.; Ward, M.S.; Fotheringham, A.K.; Zhuang, A.; Borg, D.J.; Flemming, N.B.; Harvie, B.M.; Kinneally, T.L.; Yeh, S.-M.; McCarthy, D.A.; et al. Once daily administration of the SGLT2 inhibitor, empagliflozin, attenuates markers of renal fibrosis without improving albuminuria in diabetic $\mathrm{db} / \mathrm{db}$ mice. Sci. Rep. 2016, 6, 26428. [CrossRef] 
90. Leiter, E.H. The NOD Mouse: A Model for Insulin-Dependent Diabetes Mellitus. Available online: https://currentprotocols. onlinelibrary.wiley.com/doi/10.1002/0471142735.im1509s24 (accessed on 28 June 2021).

91. Nguyen, D.; Zhou, T.; Shu, J.; Mao, J. Quantifying chromogen intensity in immunohistochemistry via reciprocal intensity. Cancer InCytes 2013, 2. [CrossRef]

92. James, C.R.; Buckle, I.; Muscate, F.; Otsuka, M.; Nakao, M.; Oon, J.S.H.; Steptoe, R.J.; Thomas, R.; Hamilton-Williams, E.E. Reduced interleukin-2 responsiveness impairs the ability of Treg cells to compete for IL-2 in nonobese diabetic mice. Immunol. Cell Biol. 2016, 94, 509-519. [CrossRef] [PubMed] 